DEMOGRAPHIC RESEARCH

VOLUME 33, ARTICLE 16, PAGES 451-498

PUBLISHED 4 SEPTEMBER 2015

http://www.demographic-research.org/Volumes/Vol33/16/

DOI: 10.4054/DemRes.2015.33.16

Research Article

\title{
Partnership dynamics across generations of immigration in France: Structural vs. cultural factors
}

\section{Ariane Pailhé}

This publication is part of the Special Collection on "Partnership dynamics among immigrants and their descendants in Europe,” organized by Guest Editors Hill Kulu and Tina Hannemann.

\section{(C)2015 Ariane Pailhé.}

This open-access work is published under the terms of the Creative Commons Attribution NonCommercial License 2.0 Germany, which permits use, reproduction \& distribution in any medium for non-commercial purposes, provided the original author(s) and source are given credit.

See http:// creativecommons.org/licenses/by-nc/2.0/de/ 


\section{Table of Contents}

$1 \quad$ Introduction 452

$2 \quad$ Theoretical framework, previous research, and hypotheses 453

2.1 Partnership formation among immigrants 453

$2.2 \quad$ Partnership formation among descendant of immigrants 455

$3 \quad$ The French context 458

3.1 France: An old country of immigration 458

3.2 Marital trajectories in France 458

3.3 Marital practices in migrant origin societies 460

3.4 Migrant marital practices in France 462

$4 \quad$ Data and methods 463

4.1 Data 463

4.2 Analysis strategy $\quad 465$

$4.3 \quad$ Variables 465

5 Results 468

5.1 First union formation 468

5.2 The type of first union 473

5.3 The transition from cohabitation to marriage 478

$6 \quad$ Conclusion and discussion $\quad 480$

$7 \quad$ Acknowledgements $\quad 483$

References $\quad 484$

$\begin{array}{ll}\text { Appendix } 1 & 492\end{array}$

Appendix 2

$\begin{array}{ll}\text { Appendix } 3 & 496\end{array}$ 


\title{
Partnership dynamics across generations of immigration in France: Structural vs. cultural factors
}

\author{
Ariane Pailhé ${ }^{1}$
}

\begin{abstract}
BACKGROUND

Postponed union formation, declines in marriage, and increases in cohabitation represent major changes in family behavior. The question arises whether these changes have taken place among immigrants and their descendants.
\end{abstract}

\section{OBJECTIVE}

This study analyzes the integration dynamics across generations of immigrants in France by focusing on partnership formation patterns. It addresses how the socialization vs. assimilation hypothesis shapes immigrants and their descendants' first partnership formation patterns, analyzing the interplay of cultural and structural factors.

\section{METHODS}

It compares i) the timing of union formation, ii) the type of first union (cohabitation vs. marriage), and iii) the transition from cohabitation to marriage of first- and second-generation male and female immigrants from the same region of origin with those of the native-born. The data come from the Trajectories and Origins survey (2008) that oversamples immigrants and their descendants. Piecewise-constant exponential models are estimated.

\section{RESULTS}

There is a convergence towards prevailing French behavior across the generations of immigrants. Second-generation immigrants form their first union later than the first generation and the level of informal cohabitation increases. Structural factors such as higher level of education have led to changes in partnership formation patterns over generations of immigrants but the convergence is not complete, and cultural factors have a strong effect, especially for women.

\footnotetext{
${ }^{1}$ Institut national d'études démographiques (INED), France. E-Mail: pailhe@ined.fr.
} 


\section{CONCLUSIONS}

Descendants of immigrants have more choices than their parents regarding lifestyle and personal arrangements, and traditional family behaviors weaken. But first unions are still considered to be a long-term commitment rather than a trial period.

\section{Introduction}

Since the 1960s, family forms in most European countries have become more varied, in parallel with increasingly diverse and individualized family life courses. The sequence of demographic events and the pace at which they occur are now less standardized than before (Brückner and Mayer 2005; Buchmann and Kriesi 2011). Postponed union formation, declines in marriage, and increases in cohabitation represent some of the main changes in family behavior. This process of destandardization and de-institutionalization of family forms is the result of increasing individualization and a weakening of the normative constraints that shape transitions and their sequencing over the life course (Lesthaeghe and Surkyn 2004). These changes in family models have also arisen due to the changing gender system and the increasing economic independence of women and their changing roles in society (Oppenheim, Mason, and Jensen 1995). Growing economic insecurity and changes in job standards have also been major causes of the transformation of the life course (Blossfeld et al. 2005).

The question arises of whether such changes have also taken place among immigrants and their descendants, who comprise a large share of the European population. This question is important since, compared to the native-born French, differences and similarities in age at partnership formation and type of union indicate the level of adherence to norms and practices in the host society (Adserà and Ferrer 2014). The postponement of partnership formation and the rise of cohabitation are indicators that individual behaviors are less determined by tradition and more open to individual choice (Bernardt et al. 2007). They also reflect changes in women's roles (Sassler 1997). Thus, union formation patterns indicate the extent to which immigrants and their offspring integrate culturally into their host society (Algan et al. 2012). However, little attention has been paid to the timing of union formation among immigrants, and even less to the type of union they engage in (Kulu and Gonzáles-Ferrer 2014).

This paper analyzes the integration dynamics across generations of immigrants in France by focusing on partnership formation patterns. France has a long history of immigration, and individuals with an immigrant background represent $20.6 \%$ of 
the 2008 adult population (Insee 2012). They come from an extremely wide range of geographical origins. In some of these regions, unions are formed in a very similar way to the prevailing French model, i.e., widespread cohabitation, rising age at which first-time couples are formed, and frequent separations (Sobotka and Toulemon 2008). In other sending countries, marriage is almost universal, and the age at first marriage remains low. France has also adopted a specific model of integration, i.e., assimilation, by promoting the conformity of immigrants and their descendants to the ideals of the French Republic (Favell 2001). Relatively few cultural rights are granted to immigrants (Koopmans 2010), which limits the persistence of cultural differences (Huschek, Liefbroer, and de Valk 2010). This specific context should theoretically drive a convergence of partnership dynamics towards French standards.

In order to analyze this potential convergence in the absence of data that follows immigrant groups over time and over several generations, we compare the partnership dynamics of first- and second-generation immigrants from the same region of origin with those of the native-born. We analyze several outcomes: i) the timing of union formation, ii) the type of first union (cohabitation vs. marriage), and iii) the transition from cohabitation to marriage. We consider decreasing differences between generations of immigrants and the native-born to be a sign of gradual adaptation to the behaviors and norms that prevail in France. Migration patterns differ greatly between men and women, and gender roles are constructed differently in origin and destination societies. Thus, we analyze partnership dynamics by gender. The recent Trajectories and Origins survey (2008) provides an opportunity to investigate the partnership dynamics of immigrants and their descendants.

\section{Theoretical framework, previous research, and hypotheses}

\subsection{Partnership formation among immigrants}

A huge amount of research has been conducted on immigrants' partner choices (Lievens 1999; Kalmijn and van Tubergen 2006; Huschek, Liefbroer, and de Valk 2012; Safi 2008; see Adserà and Ferrer 2014 for an overview). In particular, intermarriage has been considered a sign that newcomers have perfectly integrated (Gordon 1964; Kalminj 1998). Far less attention has been devoted to the timing of their union formation and the type of union they choose. The competing theoretical hypotheses developed to analyze immigrants' fertility (Hervitz 1985; Andersson 2004; Milewski 2007) can be adapted to their partnership dynamics, since in many 
respects migration influences timetables for partnership formation (Glick 2010; Lloyd 2006).

The first hypothesis emphasizes that migration is a significant disruption in the individual life course. In particular, migrants have to adapt to a completely new marriage market, which delays partnership formation (Adsera and Ferrer 2014). Alternatively, the family formation hypothesis underscores the fact that migration and family events are interrelated. Marriage is often a reason to migrate (Kofman 2004; Lievens 1999), especially if family visas are granted to spouses, and marriage and migration occur simultaneously when selection of migrants is based on family reunification policy (Tribalat 1996). The socialization hypothesis considers that exposure to certain norms and values during an immigrant's childhood (i.e., those of their country of origin) have long-lasting effects and are dominant in shaping individual behaviors (Michaël and Tuma 1985). In particular, socially recognized norms exist for the timing and sequencing of events associated with the transition to adulthood, and thus influence partnership dynamics (East 1998). The uncertainty associated with the migration experience and the perception that the new environment threatens these values can even result in an over-emphasis of values (Huschek, de Valk, and Liefbroer 2011). Following this hypothesis, union formation patterns should be close to the practices in the country of origin. By contrast, the assimilation or adaptation hypothesis emphasizes adapting immigrant behaviors to the environment and norms of the society of settlement (Foner 1997). Migration transforms the normative, social, and economic contexts in which the decision is taken to form a union, and the partnership dynamics should converge to those of the host country. This adaptation can be reinforced by the fact that immigrants are generally a highly selected group from their country of origin. This selection may be based on skills required in the host country, which may impact family behaviors.

Studies devoted to immigrants' partnership formation generally compare them to the individuals in the host society. They show that most immigrant groups tend to marry earlier than the natives and are less prone to cohabit (Lesthaeghe and Surkyn 1995, Bernhardt et al. 2007, Kulu et al. 2014). In line with the socialization hypothesis, the spread of cohabitation among immigrants depends on norms and practices that prevail in the countries of origin (Cortina Trilla, Esteve, and Domingo 2008). Thus both the socialization and assimilation hypotheses explain their partnership formation pattern: immigrants create a new family life that is influenced by both past cultural customs and the ways of the new country, but that also differs from both (Foner 1997). Therefore immigrant assimilation takes time and occurs over several generations (Alba and Nee 2003). 


\subsection{Partnership formation among descendant of immigrants}

When immigrants come from societies in which the transition to adulthood has characteristics other than those of the society in which they grow up, the socialization process of their descendants is characterized by potentially conflicting injunctions (de Valk and Liefbroer 2007; Hamel et al. 2012). Being attached to two cultural heritages, their behaviors are shaped by both the dominant norms of the society in which they grow up and by the intergenerational transmission of family values and practices (Huschek, Liefbroer, and de Valk 2010; Collet and Santelli 2012). Thus both the adaptation and the socialization hypotheses apply to their partnership dynamics. Specific family values and norms can be expected to persist among descendants of immigrants, because their core identity would be scrutinized if they were to renounce their own traditional values and norms regarding the appropriate timing and type of union formation (Arias 2001; Schnapper 1991). In addition, the reality of belonging to a minority community may make the intergenerational transmission of family values an important issue among immigrants. Conversely, the values and behaviors adopted by descendants of immigrants can shift towards those of the majority population by means of school socialization, the media, and friends from the host culture (Huschek, de Valk, and Liefbroer 2011).

With the second generation coming of age and thanks to the availability of specific surveys such as the TIES survey, research on the timing of union formation has been growing, especially for second generation Turks and Moroccans, who are the largest immigrant groups in Europe (de Valk and Milewski 2011). A large body of research has analyzed ideas about the appropriate timing and sequencing of family formation among descendants of immigrants (de Valk and Liefbroer 2007), and it was found that these ideas differ from the native population. For instance, those of Turkish descent prefer younger ages at marriage than the native Dutch (de Valk and Liefbroer 2007). Studies investigating the timing of these events conclude that second-generation Turkish and Moroccan immigrants enter their first union relatively early in comparison to the respective young native adults (Bernardt et al. 2007 in Sweden; de Valk 2006 in the Netherlands; Lievens 1999 in Belgium; Milewski and Hamel 2010 in France; Soehl and Yahirun 2011 in Germany). Others conclude that those entering endogamous unions have a younger age at union formation than those entering exogamous unions in Germany (Soehl and Yahirun 2011). The type of first union has been investigated less. In this respect the second generation also deviates from their parents. For instance, young, second-generation Turks in the Netherlands declare that they would like to cohabit first and marry later (de Valk 2006). However, marriage without prior unmarried cohabitation is still the 
major type of union among second-generation Turks, especially for women (Milewski and Hamel 2010).

This study addresses how socialization vs. adaptation shapes immigrants and their descendants' partnership formation patterns in the French context. The 'assimilation or adaptation' hypothesis predicts that immigrants are expected to adapt their behavior during their time spent in France and over generations.

H1: A larger gap in union formation behavior between first and second generations is a sign of gradual adaptation to behaviors and norms that prevail in France.

This hypothesis predicts that union formation behavior among the descendants of immigrants converges to that of native-born men and women, and that cohabitation among immigrants' descendants is higher than that of their parents' generation. According to this hypothesis, we also expect that immigrants from earlier immigration waves (Southern Europe and the Maghreb) have adapted more than more recent immigrants.

Alternatively, the socialization hypothesis underlines the effect of exposure to values during childhood as a key determinant of individual behaviors. Immigrants in France come from different origins, and thus bring a variety of human, economic, and social capital. Since norms and practices vary in terms of the appropriate timing of union formation and cohabitation, union formation patterns are expected to differ between origins and between first and second generations.

H2a: The greater the cultural differences between immigrants and the native population, the larger the difference in union formation patterns is likely to be.

According to this hypothesis, we expect that the timing and type of union for immigrants and the second generation from Southern Europe are more likely to be close to those of the native French. In particular, they are more likely to cohabit than immigrants and the children of immigrants from Asia, Turkey, North Africa, and Sub-Saharan Africa.

As for the mainstream population (South 2001; Axinn and Thornton 1992), parental background is an important factor in explaining the transmission of preferences and the timing of first unions (de Valk and Liefbroer 2007; Huschek, Liefbroer, and de Valk 2010). Relatively modern attitudes towards family formation and postponed entry into first union are found among second-generation young adults whose parents have high human capital, small family size, and low religious commitment (Idema and Phalet 2007).

H2b: Children of immigrant parents with more traditional family values and low socio-economic status are more likely to form a union earlier and to marry directly. 
Education is one of the most important determinants of marriage prevalence and timing (Ní Bhrolcháin and Beaujouan 2012). In particular, higher educational attainment leads to greater autonomy in life course choices, and it increases the cost of union. Hence, educational attainment has a strong delaying effect on union formation, as union formation is usually seen as incompatible with educational enrolment (Blossfeld and Huinink 1991). The level of education also shapes both individual preferences and the size of the marriage market (Furtado 2012). In the case of immigrants' descendants, a higher level of education also leads to deviations from the parents' views and toward a stronger preference for autonomy in life course choices (Collet and Santelli 2012). It also provides higher socio-economic resources, which help to impose the offspring's own choices on their parents. Thus, higher education causes partnership timing to converge with that which prevails among the majority population (Arias 2001). Empirical studies show that own level of completed education has more impact than the parents' level, especially for women (Bernardt et al. 2007). The higher transition rates to a first union among women in the Turkish-origin group appear to be related mainly to a lower level of education among Turkish immigrants' descendants in France (Milewski and Hamel 2010). Thus, a convergence with the timing that prevails among the native population occurs as the level of education increases.

H3: Increasing levels of higher education leads to a postponement of union formation and to higher prevalence of cohabitation.

Assimilation theories (Alba and Nee 2003) and segmented assimilation theories (Portes and Zhou 1993) emphasize the importance of context for secondgeneration assimilation trajectories. Groups follow several paths of adaptation that are based on disparities in their parents' human and social capital, family structure, and modes of incorporation in the host society (Portes, Fernandez-Kelly, and Haller 2009). Some groups of second-generation immigrants are raised in less favorable conditions than others: their parents have low-status jobs or are unemployed, and they may live in segregated and deprived areas. Moreover, some groups of secondgeneration immigrants face discrimination in the labor market and suffer from high unemployment levels (Meurs, Pailhé, and Simon 2006). These unequal living conditions among groups shape social relations and affect partnership formation (Crissey 2005; Smock and Manning 1997; Glick et al. 2006). Living in segregated areas limits contact with the native population and thus behavioral adaptation to the norms of the settlement society. Moreover, the material dependence of secondgeneration immigrants may reinforce parental influence on decisions regarding union formation (Huschek, Liefbroer, and de Valk 2010). Finally, by committing to their cultural identity in the face of poor prospects, they may be prone to maintaining traditional family values (Collet and Santelli 2012). 
H4: Immigrants and their descendants who are in a disadvantaged position (especially in the labor market) postpone partnership formation, which explains differences according to origin.

Few studies have investigated immigrant groups from a gendered perspective, and most have been devoted mainly to preferences rather than behaviors. Idema and Phalet (2007) show that second-generation Turkish daughters in Germany shift towards more egalitarian values, particularly when their mothers are highly educated, whereas sons remain as traditional as their fathers. Educational level has a strong effect on egalitarian preferences among second-generation Turks (Bernardt et al. 2007; Diehl, Koenig, and Ruckdeschel 2009; Huschek, Liefbroer, and de Valk 2011). Due to huge gender differences in countries of origin and to higher parental control over daughters than sons, we expect partnership formation patterns to differ by gender.

H5. Partnership formation among female descendants is closer to that of their parents, i.e., they are younger at partnership formation and have a higher rate of direct marriage.

\section{The French context}

\subsection{France: An old country of immigration}

France has a long history of immigration (Schor 1996; Noiriel 2006). Mass immigration to France began as early as the middle of the 19th century as a result of labor shortages created by industrial growth. At the beginning of the 1930s, 2.7 million immigrants (6.6\% of the total population) were living in France, which had the second largest number of immigrants after the USA. In the post-war years and during the economic upturn of the 1950s and 1960s, immigration was encouraged in order to assist France's economic reconstruction. This mainly (single) male (unqualified) labor migration reached its peak in the 1960-74 period. In 1974 the French government officially stopped immigration other than family reunification in response to the perceived increasing number of immigrants entering the country and to the growing economic crisis. In spite of incentives to return to their home countries, many immigrants remained in France and were joined by their families. Thus immigration continued to rise and was henceforth female dominated. As family reunification was the most important channel of immigration, successive restrictive immigration policies failed to stop immigration flows. In 2010 the French metropolitan population (i.e., France without its overseas departments) consisted of $10.7 \%$ immigrants (5.4 million). Since immigration started a long time ago, the 
descendants of immigrants represent a significant share of the adult population: 10.5\% in 2008 (Insee 2012).

The composition of immigration flows and the immigrant population according to country of origin changed over time. After the Second World War, the majority of immigrants came from Southern Europe (Italy, Spain, and Portugal). Subsequently France received more and more immigrants from its former colonies in North and Sub-Saharan Africa, as well as Southeast Asia. From the middle of the 1950s the Maghrebis (i.e., those from Algeria, Morocco, and Tunisia) and the Turkish formed the most significant groups of new immigrants. Migration from Southeast Asia (Vietnam, Cambodia, and Laos) took place later and over a short period (mid-1970s to mid-1980s). Immigration from other EU-27 countries and from Sub-Saharan Africa (Senegal, Mali) is more recent, and the latter is gaining in significance.

\subsection{Marital trajectories in France}

The dynamics of how families are constituted have changed dramatically during the past 50 years in France. As in many other European countries, growing individualization and weakened normative constraints have shaped possible, acceptable, and desirable demographic transitions and their sequencing over the life course (Lesthaeghe 1995, 2010; Oppenheim, Mason, and Jensen 1995). Furthermore, formal marriage has lost ground to cohabitation, the conjugal bond has weakened, and marital trajectories have become more complex (Pailhé et al. 2014). While in the 1960s marriage was nearly universal in France, it is no longer a norm that applies to everyone. Hence, about $85 \%$ of men and women born in the mid-1950s were ever-married at age 49; the proportion is estimated to have fallen to $63 \%$ for men and $65 \%$ for women in the cohorts born in the mid-1970s (Mazuy, Barbieri, and d'Albis 2013). Direct marriages have become increasingly rare. Since the mid-1980s only 1 first union out of 10 has begun with a formal marriage, while in 1970 it was still more than 5 out of 10 (Toulemon, Pailhé, and Rossier 2008). Cohabitation has increased dramatically in all social groups and has become more often an alternative rather than a stepping-stone to marriage (Prioux 2009). Therefore, marriage is no longer a precondition for childbearing. Since there is no legal difference between the rights of children born inside or outside marriage, the number of births outside marriage began to increase at the end of the 1970s, and now outnumber births within marriage: while non-marital births made up about $6 \%$ of all births in the 1960s, they accounted for 57\% of total births in 2012 (Mazuy, Barbieri, and d'Albis 2013). Two-thirds of first births are non-marital births, while 
second and third births stand at $44 \%$ and $35 \%$, respectively. The majority of couples do not turn their union into marriage when they have a child: $60 \%$ of couples cohabiting at first childbearing are still cohabiting when they have their second child (Charton 2009).

As a result of changes in norms and other structural factors, such as additional years spent in education, first unions take place at higher ages than before. The median age at first union formation increased from 23.8 for men born in 1955 to 26.0 for men born in 1971, according to the Etude de l'histoire familiale survey conducted in 1999 (Prioux 2005). For women the corresponding figures are 21.5 for women born in 1955 and 23.7 for women born in 1974. At the same time, the age at first partnership became more diverse. Age at first marriage was also postponed: first marriages in these cohorts were contracted, respectively, at age 25.0 and 30.6 for men, and 22.9 and 28.9 for women.

\subsection{Marital practices in migrant origin societies}

Marital practices differ greatly across immigrants' countries of origin. To illustrate these differences, Table 1 reports the mean age at marriage and the percentage of ever-married individuals between ages 25-29 for a selection of the main countries of origin of immigrants in France. The selected year approximates the period when the majority of migrants from each origin came to France. In Southern European countries the mean age at marriage was close to that of France or even a bit higher. In these countries, the process of de-standardization and de-institutionalization of family forms occurred much later than in France (Pailhé et. al 2014). In particular, postponement of union formation and the rise in the frequency of cohabitation began later (Billari and Liefbroer 2010), but the marital practices resemble each other more than those in the other immigrant-origin societies. Partnership dynamics differ significantly from the French in Turkey and Northern and Sub-Saharan Africa - even if there have been rapid changes in the last 20 years. In Sub-Saharan and North African countries the standards of early marriage for women and a large age difference between spouses prevail. In Turkey and the countries of Southeast Asia also, the age at marriage for women is lower when compared to the French population during the same period, but age differences between spouses are lower than in African countries. In these countries, marriage is almost universal and cohabitation is very rare. In North Africa and Turkey, young people stay with their parents until they get married (Milewski and Hamel 2010). In African societies, marriage is a key event that signals formal recognition of the union within the society. Communities are deeply involved in these decisions and the family has 
control over the choice of spouse (Thiriat 1998). Consanguineous marriages between cousins are preferred in these societies, in order to assure the continuation of the family line (Milewski and Hamel 2010; Collet and Santelli 2012).

Table 1: Data on marital status in immigrants' countries of origin

\begin{tabular}{|c|c|c|c|c|c|}
\hline & \multirow[t]{2}{*}{ Year } & \multicolumn{2}{|c|}{$\begin{array}{l}\text { Mean age at first } \\
\text { marriage }\end{array}$} & \multicolumn{2}{|c|}{$\begin{array}{c}\text { Share of ever } \\
\text { married in age } \\
\text { group 25-29 (\%) }\end{array}$} \\
\hline & & Women & Men & Women & Men \\
\hline France & 1970 & 22.3 & 25.2 & 83.5 & 71.9 \\
\hline Spain & 1970 & 23.7 & 27.5 & 73.4 & 54.0 \\
\hline Italy & 1971 & 22.6 & 27.2 & 76.8 & 54.3 \\
\hline Portugal & 1970 & 23.2 & 25.6 & 75.0 & 69.2 \\
\hline Morocco & 1982 & 22.2 & 27.1 & 83.0 & 55.2 \\
\hline $\begin{array}{l}\text { Democratic Republic of } \\
\text { Congo* }\end{array}$ & 1984 & 20.0 & 24.9 & 89.1 & 71.1 \\
\hline Tunisia & 1984 & 24.3 & 28.1 & 75.4 & 48.1 \\
\hline France & 1985 & 24.7 & 26.6 & 72.8 & 57.8 \\
\hline Algeria & 1987 & 23.7 & 27.7 & 77.9 & 50.6 \\
\hline Mali & 1987 & 18.9 & 28.1 & 94.2 & 48.4 \\
\hline Vietnam & 1989 & 23.1 & 24.4 & 82.3 & 76.9 \\
\hline Turkey & 1990 & 22.0 & 25.0 & 87.2 & 74.2 \\
\hline Senegal* & 1997 & 21.5 & $\mathrm{n} / \mathrm{a}$ & 83.5 & 36.2 \\
\hline Cambodia & 1998 & 22.5 & 24.2 & 83.2 & 78.6 \\
\hline Cameroon* & 1998 & 20.2 & 26.7 & 89.1 & 58.1 \\
\hline Ivory Coast* & 1998 & 21.9 & 28.0 & 82.7 & 45.8 \\
\hline France & 1999 & 30.7 & 32.9 & 33.8 & 20.0 \\
\hline
\end{tabular}

Note: Selected years for the average age at marriage are those closest to the median year of migration for each origin. Major African countries are selected.

* Including consensual unions

Source: United Nations, Department of Economic and Social Affairs, Population Division. World Marriage Data 2012.

In non-European countries of origin, gender relations also differ significantly when compared to France. In these countries men must be in a position to provide household income and they are responsible for protecting their wives, while women are in charge of the family. Moreover, women in Muslim societies have to guarantee the preservation of the family honor and reputation. In particular, pre- 
marital sex is - or was ${ }^{2}$ - illegal, as it constitutes an offense to the family honor (Milewski and Hamel 2010; Collet and Santelli 2012). Women's sexuality is strictly controlled and families encourage early marriage, since it guarantees that a woman's reputation and responsibility for her are taken care of, and it also increases the chances of a better partner.

\subsection{Migrant marital practices in France}

In France, male migration is primarily a migration of young single men, while the share of women who meet their partner before migration is significantly higher (Pailhé and Hamel 2015). Immigrant men wait until they are properly settled in France before starting a family: they postpone partnership formation until later than both the native French and men in their country of origin. This postponement is increasing over cohorts and is particularly high for migrants from the Maghreb and Sub-Saharan Africa, while it occurs earlier for migrants from Turkey and Portugal (Tavan 2005). Female immigrants more frequently marry before coming to France. They also postpone partnership formation in comparison to the practice in their country of origin, but in 1999 their timing was close to that of French female natives.

Partnership behaviors of Turkish and African second generations in France are influenced by two conflicting sets of values. On the one hand, their parents' value systems are marked by patriarchal values and Muslim traditions. On the other hand, they experience the more individualistic values of French society. French people of African and Turkish descent are more conservative with regard to certain values, especially those that ban sex before marriage for girls (Brouard and Tiberj 2005). Many Muslim women appear to endorse this norm (Andro 2012). In parallel to this conservatism, second-generation Turks and Africans appear to be more open to modern values regarding cohabitation and egalitarian gender roles (Streiff-Fénart 2006; Collet and Santelli 2012). As far as behaviors are concerned, secondgeneration Turks form their first union earlier and rarely cohabit (Milewski and Hamel 2010). On the other hand, young second-generation immigrants from Southern Europe and the Maghreb enter adulthood later than the native French (Hamel, Moguérou, and Santelli 2011).

Gender differences during the transition to adulthood are strong among descendants of immigrants from Turkey and Northern and Sub-Saharan Africa: sons have a lot of autonomy, while daughters are more strictly supervised, especially when they go out (Hamel, Moguérou, and Santelli 2011). However,

${ }^{2}$ In Turkey it was illegal until the 2000s. 
immigrants' parents strongly encourage education for their daughters, which is a factor of emancipation (Collet and Santelli 2012).

\section{Data and methods}

\subsection{Data}

The data we use come from the Trajectories and Origins (TeO) survey conducted in 2008 by the French National Institute of Demography (INED) and the French National Statistical Office (INSEE). This survey is particularly appropriate since it investigates the living conditions and social trajectories of immigrants and secondgeneration immigrants. Twenty-two thousand people living in France $^{3}$ were interviewed, and immigrants and their descendants were oversampled (Beauchemin, Hamel, and Simon 2010). The native French and immigrants were 18-60 years old (1948-90 cohorts), while descendants of immigrants were 18-50 years old (195890 cohorts).

The survey contains retrospective biographical data concerning family and employment history, in particular dates (month and year) of first and current coresidential union, first and current marriage, and first separation. The survey also contains standard socioeconomic information and very detailed information on family background; e.g., parents' social class, religious affiliation, level of education, number of siblings, language skills, etc. There is detailed information on migration origin: individual's place of birth and nationality at birth, parent's place of birth and nationality at birth, year of arrival in France, and reason for immigration. Native French are defined as individuals born to two French-born parents. Immigrants are persons born abroad without French nationality at birth. Descendants of immigrants are persons born in metropolitan France with at least one immigrant parent. Even though they are not immigrants according to French law, individuals born in overseas French departments or whose parents were born in overseas French departments were excluded from the analysis, since they have specific partnership patterns. Because we are interested in partnership formation patterns in the French context, we only take into consideration unions among immigrants that began after arrival in France, as did Nadja Milewski (2007) in her study of entry into parenthood ${ }^{4}$. Immigrants who experienced first union formation in the same year as immigration are also excluded in order to leave out cases where

\footnotetext{
${ }^{3}$ The survey covers people living in metropolitan France, i.e., excluding overseas departments.

${ }^{4}$ We thus leave out the family-formation hypothesis.
} 
union formation and migration are jointly determined. We mainly exclude women ${ }^{5}$, who migrate less often on their own initiative. The immigrants we select, especially women, entered their first union at higher ages than those who are excluded from our sample (Pailhé and Hamel, 2015). These migrants may adapt more readily to the partnership practices of the settlement country. Cases with missing information, with entry into first union prior to age 15 , or with inconsistent dates in their life history, were also excluded from the analysis ${ }^{6}$. Our sample consists of 14,603 individuals. Table 2 displays the sample size for each migrant group and the share of each group in respect to the whole population.

Table 2: Distribution of population by origin, sex, and cohort

\begin{tabular}{lcccccc}
\hline & \multicolumn{2}{c}{ Women } & \multicolumn{2}{c}{ Men } & \multicolumn{2}{c}{ Total } \\
\hline & $\mathrm{N}$ & $\%^{(\mathrm{a})}$ & $\mathrm{N}$ & $\%^{(\mathrm{a})}$ & $\mathrm{N}$ & $\%^{(\mathrm{a})}$ \\
Immigrants & 1,747 & 4.4 & 2,341 & 6.1 & 4,088 & 5.3 \\
G1 Maghreb & 505 & 1.8 & 734 & 2.8 & 1,239 & 2.3 \\
G1 Sub-Saharan & 366 & 0.7 & 473 & 0.8 & 839 & 0.8 \\
Africa & & & & & & \\
G1 Southeast Asia & 232 & 0.2 & 327 & 0.3 & 559 & 0.3 \\
G1 Turkey & 168 & 0.3 & 264 & 0.5 & 432 & 0.4 \\
G1 Southern Europe & 476 & 1.4 & 543 & 1.7 & 1,019 & 1.5 \\
Immigrants' & 3,597 & 8.8 & 3,210 & 9.2 & 6,807 & 9.0 \\
descendants & & & & & & \\
G2 Maghreb & 1,341 & 3.7 & 1,056 & 3.4 & 2,397 & 3.6 \\
G2 Sub-Saharan & 440 & 0.4 & 370 & 0.5 & 810 & 0.4 \\
Africa & & & & & & \\
G2 Southeast Asia & 271 & 0.2 & 297 & 0.3 & 568 & 0.3 \\
G2 Turkey & 233 & 0.3 & 210 & 0.2 & 443 & 0.3 \\
G2 Southern Europe & 1,312 & 4.2 & 1,277 & 4.8 & 2,589 & 4.4 \\
Native & 1,962 & 86.8 & 1,746 & 84.7 & 3,708 & 85.7 \\
Total & 7,306 & 100.00 & 7,297 & 100.00 & 14,603 & 100.00 \\
\hline
\end{tabular}

Source: Trajectories and Origins survey (TeO), INED-INSEE, 2008.

(a) The percentages are computed using sampling weights to give the proportion of these groups in the total population.

5 2,135 migrants (718 men and 1,417 women) were excluded. 1,389 entered a first union prior to migration and 746 entered a first union in the year they migrated.

${ }^{6} 90$ individuals entered a first union before age 15 and 329 individuals have missing information for the date of first union. 


\subsection{Analysis strategy}

In order to analyze the socialization vs. adaptation hypothesis, we analyze variations in partnership formation patterns among immigrants and second generations, as well as across immigrant groups. The analysis is divided into three parts. First we describe the differences in age at first union across generations of immigrants and origins. Univariate Kaplan-Meier estimates are used to describe differences in the timing and prevalence of a first union. The analyses are stratified by sex and adjusted for the stratifying nature of the survey ${ }^{7}$ by using sampling weights. In order to determine whether the observed differences in the timing of partnership formation are culturally or structurally determined, piecewise-constant exponential models are estimated. In this semi-parametric continuous time duration model, the duration time is split into several intervals. The hazard rate is allowed to differ in different time periods but is assumed to be constant within any given time period. We estimate the timing (in months) of entry into first union, with the risk time starting at age 15 for second-generation immigrants and native French. For firstgeneration immigrants the risk of entering a first union is calculated on the basis of their age at arrival in France. Cases are censored at the interview date or at age 45; whichever comes first.

Second, the timing of first cohabitation and first direct marriage are estimated as competing risks. In the event of a competing risk, cases are censored at the interview date or at age 45 . Third, we analyze the duration between cohabitation and marriage in order to estimate whether cohabitation is a stepping-stone to marriage. For this analysis, exposure time starts at the beginning of first cohabitation.

\subsection{Variables}

Unions are defined as couples living together under the same roof for 6 months or more. First union is defined as the first cohabiting union or the first marriage lasting at least 6 months. First marriage is defined as the first religious or civil marriage. The same set of control covariates is used in the multivariate analysis, with the covariates being added step by step. The distribution of control variables is presented in Table 3. The baseline model (Model 1) controls for origin, cohort, and

\footnotetext{
${ }^{7}$ Sampling weights were calibrated so that the estimated counts corresponded with the population of France in 2008. Corrections for non-response and post-stratification (ranking ratio) were made using annual census survey data for 2008 and variables for sex, age, matrimonial status, country of birth, nationality, region, size of the settlement, and type of housing.
} 
fertility. To test our two first hypotheses, immigrants and their descendants are distinguished and several groups are selected that are representative of the main immigration groups with a variety of human, economic, and social capital. The following aggregated regions of origin are used: the Maghreb (Algeria, Tunisia, and Morocco), Sub-Saharan Africa (Senegal, Mali, Cameroon, Guinea, etc.), Southeast Asia (Vietnam, Cambodia, and Laos), Turkey and Southern Europe (Italy, Spain, and Portugal). Four birth cohorts are distinguished: born in 1948-1960, in 19611970, in 1971-1980, and in 1981-1990. Since premarital pregnancy among single women increasingly prompts transition into union formation (Perelli-Harris et al. 2012), we include a time-varying variable by computing the year of first birth minus 9 months. In order to test if socio-economic and cultural position of the family shape the decision to form a union (H2b), Model 2 controls for background variables. Social background is taken into account through parents' social class and the level of religiosity, i.e., the level of importance given to religion during childhood education. To examine whether behaviors are related to educational level (H3) we include the level of education (Model 3), which is introduced in the model as four dummy variables: basic education, low professional education, secondary education, and high education (university) ${ }^{8}$. To test how socio-economic resources shape the timing of partnership formation (H4), access to stable employment (i.e., a job lasting at least one year) is computed for each calendar year (Model 4). This time-dependent variable is lagged by one year. A time-varying dummy variable for school enrollment is also added, as school enrollment may be incompatible with union formation (Glick et al. 2006). It is expected to delay the entrance into union, education level being controlled for. In order to analyze whether socio-cultural background, educational attainment, and socio-economic resources shape entry into partnership and the type of union, separate analyses by origin group are also implemented. All models are estimated separately for men and women in order to test H5.

${ }^{8}$ Educational level is measured by French standards. Since most countries of origin were former French colonies, the educational system is modeled on the French system. This basic partition into 4 levels also fits with European countries and Turkey. 
Table 3: Distribution of control variables

\begin{tabular}{|c|c|c|}
\hline & \multicolumn{2}{|c|}{ Proportion } \\
\hline & Women & Men \\
\hline G1 Maghreb & 6.8 & 9.1 \\
\hline G1 Africa & 4.2 & 4.5 \\
\hline G1 Southeast Asia & 3.4 & 5.2 \\
\hline G1 Turkey & 2.0 & 3.1 \\
\hline G1 Southern Europe & 6.6 & 7.5 \\
\hline G2 Maghreb & 18.7 & 15.0 \\
\hline G2 Africa & 5.0 & 4.2 \\
\hline G2 Southeast Asia & 3.0 & 3.2 \\
\hline G2 Turkey & 2.6 & 2.5 \\
\hline G2 Southern Europe & 19.5 & 19.6 \\
\hline Native French & 28.1 & 26.0 \\
\hline Aged 15-19 & 52.8 & 50.6 \\
\hline Aged 20-24 & 33.3 & 32.0 \\
\hline Aged 25-29 & 9.0 & 11.5 \\
\hline Aged 30-34 & 3.0 & 3.8 \\
\hline Aged 35-40 & 1.3 & 1.6 \\
\hline Aged 40+ & 0.6 & 0.6 \\
\hline 1948-60 Cohort & 16.2 & 18.7 \\
\hline 1961-70 Cohort & 29.3 & 28.4 \\
\hline 1971-80 Cohort & 31.7 & 30.7 \\
\hline 1980-90 Cohort & 22.8 & 22.2 \\
\hline Child conception & 5.6 & 2.7 \\
\hline Religion not important & 23.7 & 27.1 \\
\hline Religion a little important & 28.9 & 28.2 \\
\hline Religion rather important & 22.2 & 20.8 \\
\hline Religion very important & 25.2 & 24.0 \\
\hline Farmer & 3.8 & 5.8 \\
\hline Craftsman, shopkeeper & 13.9 & 13.5 \\
\hline Executive & 8.5 & 6.8 \\
\hline Intermediary profession & 11.5 & 11.8 \\
\hline Skilled worker/employee & 37.9 & 38.5 \\
\hline Unskilled worker/employee & 24.5 & 23.6 \\
\hline No diploma, primary education & 25.0 & 29.2 \\
\hline Professional education & 23.6 & 28.2 \\
\hline Secondary education & 20.1 & 17.1 \\
\hline Tertiary education & 31.3 & 25.6 \\
\hline In education & 54.3 & 48.2 \\
\hline Stable employment & 49.6 & 54.5 \\
\hline $\mathrm{N}$ person-months & 22,737 & 24,393 \\
\hline
\end{tabular}

Source: Calculations based on Trajectories and Origins survey (TeO), INED-INSEE, 2008

Coverage: Immigrants aged 18-60 who arrived single in metropolitan France, Native French aged 18-60, and descendants of immigrants aged $18-50$. 


\section{Results}

\subsection{First union formation}

The timing of union formation varies widely across origins and between the sexes (Table 4). For men and women alike, immigrants generally enter into their first union later than the native French. However, immigrants from Southern Europe and Turkey are an exception, as their median age at first union formation is close to that of the native French; i.e., around 22 years old for women and 24 years old for men. Immigrants from the Maghreb and Southeast Asia form their first union three to four years later, and those from Sub-Saharan Africa much later: at 28.4 years for women and 29.5 for men.

Since the second generations are still young - except those from Southern Europe and, to a lesser extent, those from the Maghreb ${ }^{9}$ - only a small proportion had experienced a first union at the time of the survey: about one quarter of male descendants of Sub-Saharan African or Southeast Asian immigrants and more than 4 out of 10 men of Maghrebian or Turkish descent. The proportion is higher among women, as they form their first union earlier: 35\% for descendants of Sub-Saharan African immigrants, $46 \%$ for Southeast Asian immigrants, 59\% for Northern African immigrants, and $49 \%$ for Turkish immigrants. All groups of descendants form their first union later than the native French, partly because they belong to younger cohorts. The gap with respect to the native French narrows for secondgeneration immigrants from the Maghreb, Southeast Asia, and Sub-Saharan Africa, especially for women. Conversely, second generations from Turkey ${ }^{10}$ and Southern Europe and men from Sub-Saharan Africa enter into union later than immigrants of the same origin.

\footnotetext{
${ }^{9}$ The average age is, respectively, 34 and 29 years old for descendants of immigrants from Southern Europe and Maghreb, while other descendants' average age is about 25 years old.

${ }^{10}$ The median age at first union for female descendants of Turkish immigrants is two years higher than that given by the TIES survey. This difference may be explained by: the different sampling procedure (only two cities for TIEs while $\mathrm{TeO}$ was a national survey); the low precision, given the small sample size for this group in each survey (about 218 women for Ties, 233 for TeO); and the varying proportion of women who experienced a first union across surveys ( $41 \%$ for Ties, $49 \%$ for TeO).
} 
Table 4: $\quad$ First union formation, by origin, and sex

\begin{tabular}{lllll}
\hline & \multicolumn{2}{c}{ Median age } & \multicolumn{2}{c}{ \% with first union at interview date } \\
\hline Immigrants & Women & Men & Women & Men \\
Maghreb & 26.3 & 27.7 & 76 & 82 \\
Sub-Saharan Africa & 28.4 & 29.5 & 60 & 74 \\
Southeast Asia & 25.4 & 28.8 & 86 & 84 \\
Turkey & 22.1 & 24.3 & 80 & 81 \\
Southern Europe & 22.3 & 23.9 & 93 & 94 \\
Immigrants' & & & & \\
descendants & & & & 47 \\
Maghreb & 24.2 & 27.4 & 59 & 28 \\
Sub-Saharan Africa & 27.7 & 31.5 & 35 & 27 \\
Southeast Asia & 23.7 & 27.5 & 46 & 39 \\
Turkey & 25.9 & 26.1 & 49 & 71 \\
Southern Europe & 23.2 & 25.2 & 76 & 74 \\
Natives & 22.3 & 24.3 & 82 & 67 \\
\hline Total & 22.6 & 24.6 & 71 & \\
\hline
\end{tabular}

Source: Calculations based on Trajectories and Origins survey (TeO), INED-INSEE, 2008

Coverage: Immigrants aged 18-60 who arrived single in metropolitan France, Native French aged 18-60, and descendants of immigrants aged $18-50$.

Since these cross-origin differences in median age at first union may arise from a compositional effect, we control for cohort, family background, educational attainment, and activity status (Table 5). Model 1 compares the origin groups, controlling for birth cohort and conception of a child. For immigrant women from Sub-Saharan Africa, the Maghreb, and Southeast Asia, the results are in line with those of the Kaplan-Meier non-parametric analysis: they exhibit slower entry into union compared to native French women. On the other hand, once controlled for cohort and by considering exposure time after migration, immigrant women from Turkey and Southern Europe have a higher probability of an early union. For men, all groups have faster transition to first union, except those from Southeast Asia. The great majority of immigrants from this region (men and women alike) are single when they migrate (Pailhé and Hamel 2015). They also postpone union formation after migration.

The fastest transition to first union for immigrant women from Turkey and Southern Europe is partly related to higher religiosity, lower social background, and lower level of education: consistent with our expectations, the odds ratios decrease 
in Models 2 and 3 as compared to Model 1. When employment path is controlled for, the gap increases between female Turkish immigrants and the native French: however, there is no significant difference between native French and female immigrants from Southern Europe (Model 4). In other words, the fastest transition to union formation for immigrant women from Southern Europe is related to the fastest entry into stable employment. The opposite explanation is found for female Turkish immigrants. The fastest transition to union for male Turkish immigrants does not appear to be related to socio-cultural background, level of education, or timing of entry into employment; while among Southern European immigrants, the timing of end of education and start of first employment matters.

There are huge gender differences regarding first union formation for immigrants from the Maghreb and Sub-Saharan Africa: while women delay first union as compared to natives, men form their first union more rapidly. This difference may be explained by gender differences regarding the selection of immigrants: most women from these origins have already formed a first union before migrating; thus, it is possible that those who were single at migration, i.e., those in our scope, may have characteristics that favor postponement of union formation. Controlling for religiosity, social background (Model 2), and level of education (Model 3) does not alter their relative risk of union formation, although they are closer to natives when education and employment paths are taken into account (Model 4). In particular, adding these variables removes the differences between natives and immigrant women from the Maghreb. Thus, the postponement of partnership formation appears to be linked to longer studies and/or longer entry into stable employment for immigrant women from the Maghreb. For immigrant men from North and Sub-Saharan Africa, the postponement of first union appears to be higher once the timing of schooling and employment is controlled for. For them, this postponement seems to be only weakly linked to entry into stable employment. It may be related to other factors we do not control for, such as taking longer to ask or obtain a family reunification visa for a woman living in the country of origin (Beauchemin, Borrel, and Régnard 2015).

Once controlled for cohort effect, immigrants' descendants start their first union later than the first generation, except men and women of Turkish descent and men of Southern European descent, whose risk of forming a first union is close to that of the native French (Model 1). The relative risk of union formation is significantly lower than that of natives for both male and female descendants of immigrants from the Maghreb, Southeast Asia, and Sub-Saharan Africa - the gap being higher for the latter. This relative risk of first union is relatively unaffected by the inclusion of demographic and socio-economic controls for the second generation, for both men and women. Thus, their postponement of entry into 
partnership appears to be weakly linked to differences in socio-cultural characteristics.

Table 5: $\quad$ Relative risk of first union, by sex

\begin{tabular}{|c|c|c|c|c|c|c|c|c|}
\hline & \multicolumn{2}{|l|}{ Women } & \multicolumn{5}{|c|}{ Men } & \multirow[b]{2}{*}{ Model 4} \\
\hline & Model 1 & Model 2 & Model 3 & Model 4 & Model 1 & Model 2 & Model 3 & \\
\hline \multicolumn{9}{|c|}{ Origin (Ref=Native) } \\
\hline \multirow[t]{2}{*}{ G1 Maghreb } & $0.90^{*}$ & $0.87^{\star \star}$ & $0.83^{\star \star \star}$ & 0.91 & $1.30^{\star \star \star}$ & $1.37^{\star \star \star}$ & $1.36^{\star \star \star}$ & $1.44^{\star \star \star}$ \\
\hline & (1.78) & $(2.28)$ & (3.07) & (1.57) & (5.22) & (6.02) & (5.88) & $(6.90)$ \\
\hline \multirow[t]{2}{*}{ G1 Africa } & $0.71^{\star \star \star}$ & $0.70^{\star \star \star}$ & $0.67^{\star \star \star}$ & $0.78^{\star \star \star}$ & $1.65^{\star \star \star}$ & $1.62^{\star \star \star}$ & $1.63^{\star \star \star}$ & $1.97^{\star \star \star}$ \\
\hline & $(4.65)$ & $(4.79)$ & $(5.28)$ & (3.26) & (8.23) & $(7.71)$ & (7.81) & (10.69) \\
\hline G1 Southeast & $0.88^{\star}$ & $0.85^{\star \star}$ & $0.84^{\star \star}$ & $0.87^{\star}$ & $0.83^{\star \star \star}$ & $0.82^{\star \star \star}$ & $0.82^{\star \star \star}$ & $0.87^{\star *}$ \\
\hline Asia & (1.76) & (2.11) & $(2.33)$ & (1.79) & (2.71) & (2.95) & (2.87) & (2.12) \\
\hline \multirow[t]{2}{*}{ G1 Turkey } & $1.36^{\star \star \star}$ & $1.27^{\star \star \star}$ & $1.19^{\star}$ & $1.25^{\star *}$ & $2.02^{\star \star \star}$ & $2.09^{\star \star \star}$ & $2.06^{\star \star \star}$ & $2.03^{\star \star \star}$ \\
\hline & (3.37) & (2.65) & (1.93) & $(2.44)$ & $(9.43)$ & $(9.68)$ & $(9.42)$ & (9.15) \\
\hline G1 Southern & $1.24^{\star \star \star}$ & $1.19^{\star \star \star}$ & $1.12^{\star \star}$ & 1.06 & $1.42^{\star \star \star}$ & $1.49^{\star \star \star}$ & $1.46^{\star \star \star}$ & $1.38^{\star \star \star}$ \\
\hline Europe & $(4.00)$ & (3.01) & $(2.03)$ & (1.01) & $(6.44)$ & $(7.20)$ & (6.69) & $(5.70)$ \\
\hline \multirow[t]{2}{*}{ G2 Maghreb } & $0.72^{\star \star \star}$ & $0.69^{\star \star \star *}$ & $0.67^{\star \star \star}$ & $0.69^{\star \star \star *}$ & $0.67^{\star \star \star}$ & $0.70^{\star \star \star *}$ & $0.70^{\star \star \star}$ & $0.72^{\star \star \star}$ \\
\hline & $(7.43)$ & (7.98) & $(8.37)$ & $(7.82)$ & $(7.36)$ & $(6.35)$ & (6.39) & (5.83) \\
\hline \multirow[t]{2}{*}{ G2 Africa } & $0.53^{\star \star \star}$ & $0.52^{\star \star \star}$ & $0.52^{\star \star \star}$ & $0.56^{\star \star \star}$ & $0.59^{\star \star \star}$ & $0.62^{\star \star \star}$ & $0.62^{\star \star \star}$ & $0.66^{\star \star \star}$ \\
\hline & (7.33) & $(7.40)$ & (7.53) & (6.58) & (5.01) & (4.58) & $(4.50)$ & (3.89) \\
\hline G2 Southeast & $0.78^{\star \star \star}$ & $0.80^{\star \star}$ & $0.82^{\star \star}$ & 0.90 & $0.65^{\star \star \star}$ & $0.65^{\star \star \star}$ & $0.66^{\star \star \star}$ & $0.70^{\star \star \star *}$ \\
\hline Asia & $(2.62)$ & (2.38) & (2.08) & (1.14) & (3.65) & (3.62) & $(3.47)$ & (3.03) \\
\hline \multirow[t]{2}{*}{ G2 Turkey } & 1.05 & 1.00 & 0.94 & 0.92 & 1.04 & 1.08 & 1.06 & 1.07 \\
\hline & $(0.47)$ & (0.03) & (0.57) & (0.83) & $(0.35)$ & (0.66) & (0.51) & (0.57) \\
\hline G2 Southern & $0.89^{\star \star \star}$ & $0.87^{\star \star \star}$ & $0.86^{\star \star \star}$ & $0.85^{\star \star \star}$ & 0.97 & 0.99 & 0.99 & 0.97 \\
\hline Europe & (2.77) & (3.42) & (3.64) & (3.92) & $(0.58)$ & $(0.14)$ & $(0.16)$ & $(0.69)$ \\
\hline \multicolumn{9}{|l|}{ Age (Ref= } \\
\hline \multicolumn{9}{|l|}{ 15-19) } \\
\hline \multirow[t]{2}{*}{ Aged 20-24 } & $3.01^{\star \star \star}$ & $3.03^{\star \star \star}$ & $3.11^{\star \star \star}$ & $1.69^{\star \star \star}$ & $3.70^{\star \star \star}$ & $3.71^{\star \star \star}$ & $3.73^{\star \star \star}$ & $2.42^{\star \star \star}$ \\
\hline & (33.84) & (33.98) & $(34.65)$ & (13.95) & (33.99) & $(34.06)$ & (34.15) & $(20.62)$ \\
\hline \multirow[t]{2}{*}{ Aged 25-29 } & $2.67^{\star \star \star \star}$ & $2.70^{\star \star \star}$ & $2.80^{\star \star \star}$ & $1.19^{\star \star \star}$ & $4.72^{\star \star \star}$ & $4.76^{\star \star \star}$ & $4.80^{\star \star \star}$ & $2.56^{\star \star \star}$ \\
\hline & (22.01) & $(22.25)$ & (22.92) & $(3.30)$ & (34.91) & $(35.06)$ & $(35.20)$ & (18.10) \\
\hline \multirow[t]{2}{*}{ Aged 30-34 } & $1.41^{\star \star \star}$ & $1.43^{\star \star \star *}$ & $1.48^{\star \star \star}$ & $0.63^{\star \star \star *}$ & $3.22^{\star \star \star *}$ & $3.27^{\star \star \star \star}$ & $3.30^{\star \star *}$ & $1.73^{\star * *}$ \\
\hline & $(4.43)$ & $(4.64)$ & $(5.08)$ & (5.73) & (17.87) & (18.09) & $(18.23)$ & $(7.76)$ \\
\hline \multirow[t]{2}{*}{ Aged 35-40 } & $0.61^{\star \star \star}$ & $0.63^{\star \star \star}$ & $0.66^{\star \star \star}$ & $0.28^{\star \star \star}$ & $2.03^{\star \star \star}$ & $2.07^{\star \star \star}$ & $2.10^{\star \star \star}$ & 1.13 \\
\hline & (3.33) & (3.17) & $(2.85)$ & $(8.44)$ & (6.49) & $(6.67)$ & $(6.78)$ & (1.11) \\
\hline \multirow[t]{2}{*}{ Aged $40+$} & $0.36^{\star \star \star}$ & $0.36^{\star \star \star}$ & $0.38^{\star \star \star}$ & $0.17^{\star \star \star}$ & 1.03 & 1.05 & 1.07 & $0.58^{\star \star}$ \\
\hline & (3.84) & (3.75) & (3.61) & (6.54) & $(0.14)$ & $(0.24)$ & $(0.34)$ & (2.53) \\
\hline \multicolumn{9}{|l|}{ Cohort (Ref= } \\
\hline \multicolumn{9}{|l|}{ 1948-60) } \\
\hline \multirow[t]{2}{*}{$1961-70$} & $0.84^{\star \star \star}$ & $0.84^{\star \star \star}$ & $0.86^{\star \star *}$ & $0.92^{\star \star}$ & $0.88^{\star \star \star}$ & $0.89^{\star \star \star}$ & $0.89^{\star \star \star}$ & $0.91^{\star \star}$ \\
\hline & $(4.37)$ & $(4.22)$ & (3.62) & $(2.04)$ & (3.28) & $(3.02)$ & (2.95) & $(2.27)$ \\
\hline \multirow[t]{2}{*}{ 1971-80 } & $0.86^{\star \star \star}$ & $0.86^{\star \star \star}$ & 0.93 & 1.05 & $0.91^{\star \star}$ & $0.92^{*}$ & 0.95 & 0.98 \\
\hline & (3.69) & $(3.50)$ & (1.56) & (1.09) & $(2.16)$ & (1.88) & $(1.24)$ & $(0.57)$ \\
\hline \multirow[t]{2}{*}{$1980-90$} & $0.68^{\star \star \star}$ & $0.68^{\star \star \star}$ & $0.73^{\star \star \star}$ & 0.93 & $0.61^{\star \star \star}$ & $0.62^{\star \star \star}$ & $0.64^{\star \star \star}$ & $0.72^{\star \star \star}$ \\
\hline & (7.31) & $(7.22)$ & $(5.67)$ & (1.33) & (8.23) & $(7.85)$ & $(7.40)$ & (5.45) \\
\hline $\begin{array}{l}\text { Child } \\
\text { conception }\end{array}$ & $2.43^{\star \star \star}$ & $2.41^{\star \star \star}$ & $2.18^{\star \star \star}$ & $2.18^{\star \star \star}$ & $4.10^{\star \star \star}$ & $4.10^{\star \star \star}$ & $4.02^{\star \star \star}$ & $4.06^{\star \star \star}$ \\
\hline (TV) & (19.14) & (18.80) & (16.27) & (16.37) & (26.75) & (26.67) & (26.15) & (26.41) \\
\hline
\end{tabular}


Pailhé: Partnership dynamics across generations of immigration in France

Table 5: (Continued)

\begin{tabular}{|c|c|c|c|c|c|c|c|c|}
\hline \multirow[t]{2}{*}{+2} & \multirow{2}{*}{$\begin{array}{l}\text { Women } \\
\text { Model } 1\end{array}$} & \multicolumn{7}{|c|}{ Men } \\
\hline & & Model 2 & Model 3 & Model 4 & Model 1 & Model 2 & Model 3 & Model 4 \\
\hline \multicolumn{9}{|l|}{$\begin{array}{l}\text { Religion } \\
\text { (Ref= a little } \\
\text { important) }\end{array}$} \\
\hline not important & & $\begin{array}{c}1.04 \\
(1.04)\end{array}$ & $\begin{array}{c}1.02 \\
(0.43)\end{array}$ & $\begin{array}{c}1.01 \\
(0.25)\end{array}$ & & $\begin{array}{c}1.01 \\
(0.23)\end{array}$ & $\begin{array}{c}1.00 \\
(0.13)\end{array}$ & $\begin{array}{c}0.99 \\
(0.18)\end{array}$ \\
\hline rather & & 1.06 & $1.07^{\star}$ & $1.07^{\star}$ & & 0.99 & 1.00 & 1.00 \\
\hline important & & (1.39) & (1.69) & (1.75) & & $(0.23)$ & $(0.10)$ & $(0.00)$ \\
\hline \multirow{2}{*}{$\begin{array}{l}\text { very } \\
\text { important }\end{array}$} & & $1.08^{\star}$ & $1.07^{\star}$ & $1.07^{\star}$ & & 0.97 & 0.97 & 0.96 \\
\hline & & (1.92) & (1.66) & (1.82) & & $(0.75)$ & $(0.77)$ & $(0.87)$ \\
\hline \multicolumn{9}{|l|}{$\begin{array}{l}\text { Parents' } \\
\text { occupation } \\
\text { (Ref.= } \\
\text { Unskilled } \\
\text { worker/ } \\
\text { employee) }\end{array}$} \\
\hline Farmer & & $\begin{array}{c}1.07 \\
(0.97)\end{array}$ & $\begin{array}{c}1.09 \\
(1.23)\end{array}$ & $\begin{array}{c}1.07 \\
(0.95)\end{array}$ & & $\begin{array}{l}1.29^{\star \star \star} \\
(4.11)\end{array}$ & $\begin{array}{l}1.31^{\star \star \star} \\
(4.31)\end{array}$ & $\begin{array}{l}1.25^{\star \star \star} \\
(3.63)\end{array}$ \\
\hline $\begin{array}{l}\text { Craftsman, } \\
\text { shopkeeper }\end{array}$ & & $\begin{array}{c}1.07 \\
(1.48)\end{array}$ & $\begin{array}{l}1.12^{\star \star} \\
(2.34)\end{array}$ & $\begin{array}{l}1.15^{\star \star \star} \\
(2.86)\end{array}$ & & $\begin{array}{l}1.32^{\star \star \star} \\
(5.67)\end{array}$ & $\begin{array}{l}1.35^{\star \star \star} \\
(6.08)\end{array}$ & $\begin{array}{l}1.39^{\star \star \star} \\
(6.59)\end{array}$ \\
\hline Executive & & $\begin{array}{l}0.84^{\star \star \star} \\
(2.97)\end{array}$ & $\begin{array}{c}0.95 \\
(0.89)\end{array}$ & $\begin{array}{c}1.05 \\
(0.78)\end{array}$ & & $\begin{array}{l}1.20^{\star \star \star} \\
(2.82)\end{array}$ & $\begin{array}{l}1.27^{\star \star \star} \\
(3.61)\end{array}$ & $\begin{array}{l}1.35^{\star \star \star} \\
(4.54)\end{array}$ \\
\hline $\begin{array}{l}\text { Intermediary } \\
\text { Prof }\end{array}$ & & $\begin{array}{c}0.94 \\
(1.27)\end{array}$ & $\begin{array}{c}1.03 \\
(0.50)\end{array}$ & $\begin{array}{l}1.05 \\
(0.86)\end{array}$ & & $1.14^{\star \star}$ & $\begin{array}{l}1.18^{\star \star \star} \\
(290)\end{array}$ & $1.22^{\star \star \star}$ \\
\hline $\begin{array}{l}\text { Skilled } \\
\text { worker/ } \\
\text { employee }\end{array}$ & & $\begin{array}{l}1.10^{\star \star} \\
(2.48)\end{array}$ & $\begin{array}{l}1.11^{\star \star \star} \\
(2.83)\end{array}$ & $\begin{array}{l}1.12^{\star \star \star} \\
(3.04)\end{array}$ & & $\begin{array}{l}1.14^{\star \star \star} \\
(3.38)\end{array}$ & $\begin{array}{l}1.15^{\star \star \star} \\
(3.48)\end{array}$ & $\begin{array}{l}1.15^{\star \star \star} \\
(3.63)\end{array}$ \\
\hline \multicolumn{9}{|l|}{$\begin{array}{l}\text { Education } \\
\text { (Ref=Primary) }\end{array}$} \\
\hline Professional & & & $\begin{array}{c}0.98 \\
(0.58)\end{array}$ & $\begin{array}{c}1.06 \\
(1.56)\end{array}$ & & & $\begin{array}{c}1.06 \\
(1.58)\end{array}$ & $\begin{array}{c}1.07^{\star} \\
(1.70)\end{array}$ \\
\hline Secondary & & & $\begin{array}{l}0.81^{\star \star \star} \\
(4.62)\end{array}$ & $\begin{array}{c}1.07 \\
(1.40)\end{array}$ & & & $\begin{array}{l}0.90^{\star \star} \\
(2.20)\end{array}$ & $\begin{array}{c}1.07 \\
(1.37)\end{array}$ \\
\hline Tertiary & & & $\begin{array}{l}0.72^{\star \star \star} \\
(8.15)\end{array}$ & $\begin{array}{l}1.21^{\star \star \star} \\
(4.21)\end{array}$ & & & $\begin{array}{l}0.89^{\star \star \star \star} \\
(2.74)\end{array}$ & $\begin{array}{l}1.31^{\star \star \star} \\
(6.06)\end{array}$ \\
\hline $\begin{array}{l}\text { In education } \\
\text { (TV) }\end{array}$ & & & $\begin{array}{l}0.34^{\star \star \star} \\
(21.83)\end{array}$ & & & & $\begin{array}{l}0.48^{\star \star \star} \\
(13.15)\end{array}$ & \\
\hline $\begin{array}{l}\text { Stable } \\
\text { employment } \\
\text { (TV) }\end{array}$ & & & $\begin{array}{l}1.37^{\star \star \star} \\
(7.74)\end{array}$ & & & & $\begin{array}{l}1.44^{\star \star \star} \\
(7.70)\end{array}$ & \\
\hline$N$ & 15,741 & 15,741 & 15,741 & 22,737 & 16,984 & 16,984 & 16,984 & 24,393 \\
\hline
\end{tabular}

${ }^{*} p<0.1 ; * \star p<0.05 ;{ }^{\star \star \star} p<0.01$

Source: Calculations based on Trajectories and Origins survey (TeO), INED-INSEE, 2008

Coverage: Immigrants aged 18-60 who arrived single in metropolitan France, Native French aged 18-60, and descendants of immigrants aged $18-50$.

Model 1: controlled for origin, cohort, age, child conception.

Model 2: additionally controlled for social background and religiosity.

Model 3: additionally controlled for educational level.

Model 4: additionally controlled for being in education and in stable employment.

Robust $z$ statistics in parentheses

$T V$ : time-varying variable 


\subsection{The type of first union}

Country of origin influences union formation, not just in terms of timing, but also in terms of type of union (Table 6). For the native French, nearly three-quarters of first unions start with cohabitation. On the other hand, marrying directly is very common for immigrants from Turkey: about 3 out of 4 first unions start with marriage. More than half the immigrants from the Maghreb also marry directly, this proportion being higher for women. Levels of direct marriage decrease over generations of immigration, especially among those from Southeast Asia, for whom 9 out of 10 first unions start with cohabitation. However, direct marriage remains rather common for second generations from North Africa and Turkey: more than 4 out of 10 first unions start with marriage. Whatever the origin, direct marriage remains more frequent for women than for men, especially for descendants from SubSaharan Africa and the Maghreb. More surprisingly, men from the Turkish second generation marry directly more often than women of the same origin.

Table 6: $\quad$ Type of first union, by origin and sex (\%)

\begin{tabular}{|c|c|c|c|c|}
\hline & \multicolumn{2}{|c|}{ Men } & \multicolumn{2}{|c|}{ Women } \\
\hline & Marriage & Cohabitation & Marriage & Cohabitation \\
\hline \multicolumn{5}{|l|}{ Immigrants } \\
\hline Maghreb & 57.2 & 42.8 & 65.3 & 34.7 \\
\hline Sub-Saharan Africa & 34.6 & 65.4 & 28.3 & 71.7 \\
\hline Southeast Asia & 42.7 & 57.3 & 39.5 & 60.5 \\
\hline Turkey & 78.1 & 21.9 & 76.7 & 23.3 \\
\hline Southern Europe & 47.0 & 53.0 & 49.0 & 51.0 \\
\hline \multicolumn{5}{|c|}{ Immigrants' descendants } \\
\hline Maghreb & 40.8 & 59.2 & 54.4 & 45.6 \\
\hline Sub-Saharan Africa & 12.1 & 87.9 & 35.1 & 64.9 \\
\hline Southeast Asia & 6.1 & 93.9 & 10.0 & 90.0 \\
\hline Turkey & 46.8 & 53.2 & 39.7 & 60.3 \\
\hline Southern Europe & 20.4 & 79.6 & 25.8 & 74.1 \\
\hline Natives & 25.6 & 74.4 & 30.2 & 69.8 \\
\hline Total & 28.6 & 71.4 & 33.8 & 66.2 \\
\hline
\end{tabular}


These differences between origins in the mode of partnership formation remain pronounced after controlling for cohort and conception of a child (Tables 7, Model 1). Immigrants (both men and women) are more prone to marry directly, while they are less likely to start living with a partner without being married. Immigrants from Turkey and, to a lesser extent, from North Africa, have a much higher likelihood of marrying directly than native French men and women: conversely, they have a lower risk of cohabitation. In these two groups the risk of direct marriage is very high for men, given that direct marriage is rather rare for native French men. Immigrants from Southeast Asia and Southern Europe also have a higher likelihood of direct marriage, but differences to natives are much smaller. The risk of direct marriage differs by gender for immigrants from Sub-Saharan Africa: it does not significantly differ from native French women but is much higher for men. As stated previously, this difference may come from the selection of single immigrants in these countries. Women from Sub-Saharan Africa (especially those from Central and Guinean Africa who migrate autonomously) are less prone to form a union and to marry directly (Beauchemin, Borrel, and Régnard 2015).

Compared to first-generation immigrants, direct marriage is significantly lower for male and female descendants of immigrants of all origins, which is a sign that the family patterns of second-generation immigrants converge to those of the native population. The likelihood of direct marriage does not differ from that of natives for male and female descendants of immigrants from Sub-Saharan Africa and women from Southern Europe. It is even lower for men and women of Southeast Asian descent and men from Southern Europe. Yet this convergence is slower in some groups: descendants of Turkish and North African immigrants still have higher risks of direct marriage compared to the native French, this risk being rather high for both men and women of Turkish descent. Symmetrically, their risk of cohabitation is much lower. They are less likely to cohabit than the native French, even less likely than their parents, and they postpone entry into direct marriage more than both their parents and the French. Compared with the native French, for whom cohabitation is the main mode of entry into union, the risk of cohabitation remains lower for all second-generation immigrants, except for men from Southern Europe. 
Table 7: Relative risk of direct marriage and of cohabiting union, by sex

\begin{tabular}{|c|c|c|c|c|c|c|c|c|}
\hline & $\begin{array}{l}\text { Women } \\
\text { Model } 1\end{array}$ & Model 2 & Model 3 & Model 4 & $\begin{array}{c}\text { Men } \\
\text { Model } 1\end{array}$ & Model 2 & Model 3 & Model 4 \\
\hline \multicolumn{9}{|c|}{ Risk of Direct Marriage } \\
\hline G1 Maghreb & $\begin{array}{c}2.34^{\star \star \star} \\
(10.74)\end{array}$ & $\begin{array}{l}1.81^{\star \star \star} \\
(7.16)\end{array}$ & $\begin{array}{l}1.64^{\star \star \star} \\
(5.97)\end{array}$ & $\begin{array}{l}1.75^{\star \star \star} \\
(6.59)\end{array}$ & $\begin{array}{c}3.31^{\star \star \star} \\
(15.12)\end{array}$ & $\begin{array}{c}2.75^{\star \star \star} \\
(12.16)\end{array}$ & $\begin{array}{c}2.65^{\star \star \star} \\
(11.63)\end{array}$ & $\begin{array}{c}2.80^{\star \star \star} \\
(12.23)\end{array}$ \\
\hline G1 Africa & $\begin{array}{c}0.91 \\
(0.72)\end{array}$ & $\begin{array}{c}0.79^{\star} \\
(1.75)\end{array}$ & $\begin{array}{l}0.72^{\star \star} \\
(2.39)\end{array}$ & $\begin{array}{c}0.82 \\
(1.45)\end{array}$ & $\begin{array}{l}2.64^{\star \star \star} \\
(9.10)\end{array}$ & $\begin{array}{l}2.13^{\star \star \star} \\
(6.85)\end{array}$ & $\begin{array}{l}2.15^{\star \star \star} \\
(6.93)\end{array}$ & $\begin{array}{l}2.64^{\star \star \star} \\
(8.64)\end{array}$ \\
\hline G1 Southeast Asia & $\begin{array}{l}1.37^{\star \star \star} \\
(2.64)\end{array}$ & $\begin{array}{r}1.26^{*} \\
(1.90)\end{array}$ & $\begin{array}{c}1.20 \\
(1.46)\end{array}$ & $\begin{array}{c}1.25^{\star} \\
(1.84)\end{array}$ & $\begin{array}{l}1.64^{\star \star \star} \\
(4.58)\end{array}$ & $\begin{array}{l}1.46^{\star \star \star} \\
(3.40)\end{array}$ & $\begin{array}{l}1.41^{\star \star \star} \\
(3.09)\end{array}$ & $\begin{array}{l}1.50^{\star \star \star} \\
(3.64)\end{array}$ \\
\hline G1 Turkey & $\begin{array}{c}5.20^{\star \star *} \\
(15.05)\end{array}$ & $\begin{array}{c}4.15^{\star \star \star} \\
(12.70)\end{array}$ & $\begin{array}{l}3.62^{\star \star \star} \\
(11.35)\end{array}$ & $\begin{array}{l}3.69 * * \star \\
(11.41)\end{array}$ & $\begin{array}{l}8.19^{\star \star \star} \\
(21.01)\end{array}$ & $\begin{array}{c}6.62^{\star \star \star} \\
(18.33)\end{array}$ & $\begin{array}{c}6.13^{\star \star \star} \\
(17.30)\end{array}$ & $\begin{array}{l}6.17^{\star \star \star} \\
(17.24)\end{array}$ \\
\hline G1 Southern Europe & $\begin{array}{l}1.99^{\star \star \star} \\
(8.35)\end{array}$ & $\begin{array}{l}1.56^{\star \star \star} \\
(5.17)\end{array}$ & $\begin{array}{l}1.38^{\star \star \star} \\
(3.78)\end{array}$ & $\begin{array}{l}1.30 * \star \star \\
(3.06)\end{array}$ & $\begin{array}{c}2.44^{\star \star \star} \\
(10.19)\end{array}$ & $\begin{array}{l}2.11^{\star \star \star} \\
(8.34)\end{array}$ & $\begin{array}{l}1.95^{\star \star \star} \\
(7.40)\end{array}$ & $\begin{array}{l}1.84^{\star \star \star} \\
(6.74)\end{array}$ \\
\hline G2 Maghreb & $\begin{array}{l}1.90^{\star \star \star} \\
(8.94)\end{array}$ & $\begin{array}{l}1.54^{\star \star \star} \\
(5.65)\end{array}$ & $\begin{array}{l}1.50^{\star \star \star} \\
(5.28)\end{array}$ & $\begin{array}{l}1.53^{\star \star \star} \\
(5.62)\end{array}$ & $\begin{array}{l}1.55^{\star \star \star} \\
(4.55)\end{array}$ & $\begin{array}{l}1.40^{\star \star \star} \\
(3.39)\end{array}$ & $\begin{array}{l}1.36^{\star \star \star} \\
(3.08)\end{array}$ & $\begin{array}{l}1.41^{\star \star \star} \\
(3.48)\end{array}$ \\
\hline G2 Africa & $\begin{array}{c}0.93 \\
(0.44)\end{array}$ & $\begin{array}{c}0.81 \\
(1.35)\end{array}$ & $\begin{array}{c}0.79 \\
(1.51)\end{array}$ & $\begin{array}{c}0.85 \\
(1.01)\end{array}$ & $\begin{array}{c}0.96 \\
(0.17)\end{array}$ & $\begin{array}{c}0.85 \\
(0.74)\end{array}$ & $\begin{array}{c}0.84 \\
(0.80)\end{array}$ & $\begin{array}{c}0.92 \\
(0.41)\end{array}$ \\
\hline G2 Southeast Asia & $\begin{array}{l}0.48^{\star \star \star} \\
(2.70)\end{array}$ & $\begin{array}{l}0.50^{\star *} \\
(2.51)\end{array}$ & $\begin{array}{l}0.53^{\star \star} \\
(2.28)\end{array}$ & $\begin{array}{c}0.59^{\star} \\
(1.90)\end{array}$ & $\begin{array}{l}0.34^{\star \star \star} \\
(2.61)\end{array}$ & $\begin{array}{l}0.36^{\star \star} \\
(2.47)\end{array}$ & $\begin{array}{l}0.38^{\star \star} \\
(2.33)\end{array}$ & $\begin{array}{l}0.40^{\star \star} \\
(2.21)\end{array}$ \\
\hline G2 Turkey & $\begin{array}{c}4.61^{\text {}} \\
(12.68)\end{array}$ & $\begin{array}{c}3.67^{\star \star *} \\
(10.49)\end{array}$ & $\begin{array}{l}3.25^{\star \star \star} \\
(9.43)\end{array}$ & $\begin{array}{l}3.18^{\star \star \star} \\
(9.26)\end{array}$ & $\begin{array}{l}5.15^{\star \star \star} \\
(10.58)\end{array}$ & $\begin{array}{l}4.12^{\star \star \star} \\
(8.94)\end{array}$ & $\begin{array}{l}4.00^{* \star *} \\
(8.75)\end{array}$ & $\begin{array}{l}4.13^{\star \star \star} \\
(8.92)\end{array}$ \\
\hline G2 Southern Europe & $\begin{array}{c}0.99 \\
(0.07)\end{array}$ & $\begin{array}{c}0.93 \\
(0.89)\end{array}$ & $\begin{array}{c}0.92 \\
(0.96)\end{array}$ & $\begin{array}{c}0.92 \\
(0.99)\end{array}$ & $\begin{array}{l}0.76^{\star \star \star} \\
(2.58)\end{array}$ & $\begin{array}{l}0.73^{\star \star * \star} \\
(2.88)\end{array}$ & $\begin{array}{l}0.72^{\star \star \star} \\
(3.01)\end{array}$ & $\begin{array}{l}0.70^{\star \star \star} \\
(3.22)\end{array}$ \\
\hline Risk of cohabiting $u$ & & & & & & & & \\
\hline G1 Maghreb & $\begin{array}{l}0.40^{\star \star \star} \\
(9.81)\end{array}$ & $\begin{array}{l}0.45^{\star \star \star} \\
(8.28)\end{array}$ & $\begin{array}{l}0.45^{\star \star \star} \\
(8.40)\end{array}$ & $\begin{array}{l}0.50^{\star \star \star} \\
(7.33)\end{array}$ & $\begin{array}{l}0.68^{\star \star \star} \\
(5.38)\end{array}$ & $\begin{array}{l}0.82^{\star \star \star} \\
(2.60)\end{array}$ & $\begin{array}{l}0.83^{\star \star} \\
(2.43)\end{array}$ & $\begin{array}{c}0.88^{*} \\
(1.74)\end{array}$ \\
\hline G1 Africa & $\begin{array}{l}0.64^{\star \star \star} \\
(5.21)\end{array}$ & $\begin{array}{l}0.69^{\star \star \star} \\
(4.23)\end{array}$ & $\begin{array}{l}0.69^{\star \star *} \\
(4.19)\end{array}$ & $\begin{array}{l}0.82^{\star \star} \\
(2.22)\end{array}$ & $\begin{array}{l}1.34^{\star \star \star} \\
(3.94)\end{array}$ & $\begin{array}{l}1.48^{\star \star \star} \\
(5.11)\end{array}$ & $\begin{array}{l}1.52^{\star \star \star} \\
(5.38)\end{array}$ & $\begin{array}{l}1.82^{\star \star \star} \\
(7.66)\end{array}$ \\
\hline G1 Southeast Asia & $\begin{array}{l}0.70^{\star \star \star} \\
(3.65)\end{array}$ & $\begin{array}{l}0.71^{\star \star \star} \\
(3.56)\end{array}$ & $\begin{array}{l}0.71^{\star \star \star} \\
(3.53)\end{array}$ & $\begin{array}{l}0.73^{\star \star \star} \\
(3.23)\end{array}$ & $\begin{array}{l}0.59^{\star \star \star} \\
(5.99)\end{array}$ & $\begin{array}{l}0.61^{\star \star \star} \\
(5.54)\end{array}$ & $\begin{array}{l}0.63^{\star \star \star} \\
(5.24)\end{array}$ & $\begin{array}{l}0.65^{\star \star \star} \\
(4.77)\end{array}$ \\
\hline G1 Turkey & $\begin{array}{l}0.33^{\star \star \star} \\
(5.71)\end{array}$ & $\begin{array}{l}0.35^{\star \star \star} \\
(5.37)\end{array}$ & $\begin{array}{l}0.35^{\star \star \star} \\
(5.39)\end{array}$ & $\begin{array}{l}0.37^{\star \star \star} \\
(5.03)\end{array}$ & $\begin{array}{l}0.57^{\star \star \star} \\
(3.95)\end{array}$ & $\begin{array}{l}0.67^{\star \star \star} \\
(2.72)\end{array}$ & $\begin{array}{l}0.70^{\star *} \\
(2.43)\end{array}$ & $\begin{array}{l}0.68^{\star \star \star} \\
(2.64)\end{array}$ \\
\hline G1 Southern Europe & $\begin{array}{c}0.93 \\
(0.89)\end{array}$ & $\begin{array}{c}1.00 \\
(0.04)\end{array}$ & $\begin{array}{c}0.98 \\
(0.24)\end{array}$ & $\begin{array}{c}0.93 \\
(0.91)\end{array}$ & $\begin{array}{c}1.07 \\
(0.97)\end{array}$ & $\begin{array}{l}1.24^{\star \star \star} \\
(2.81)\end{array}$ & $\begin{array}{l}1.24^{\star \star \star} \\
(2.80)\end{array}$ & $\begin{array}{l}1.17^{\star \star} \\
(2.04)\end{array}$ \\
\hline G2 Maghreb & $\begin{array}{c}0.39 * \star * \\
(15.44)\end{array}$ & $\begin{array}{c}0.43^{\star * \star} \\
(13.34)\end{array}$ & $\begin{array}{c}0.42^{\star \star \star} \\
(13.45)\end{array}$ & $\begin{array}{c}0.44^{\star * \star} \\
(13.06)\end{array}$ & $\begin{array}{c}0.46^{\star \star \star} \\
(11.55)\end{array}$ & $\begin{array}{l}0.53^{\star \star *} \\
(9.30)\end{array}$ & $\begin{array}{l}0.54^{\star \star \star} \\
(9.07)\end{array}$ & $\begin{array}{l}0.55^{\star \star \star} \\
(8.70)\end{array}$ \\
\hline G2 Africa & $\begin{array}{l}0.40^{\star \star \star} \\
(8.66)\end{array}$ & $\begin{array}{l}0.45^{\star \star \star} \\
(7.65)\end{array}$ & $\begin{array}{l}0.45^{\star \star \star} \\
(7.67)\end{array}$ & $\begin{array}{l}0.48^{\star \star \star} \\
(6.85)\end{array}$ & $\begin{array}{l}0.48^{\star \star \star} \\
(6.05)\end{array}$ & $\begin{array}{l}0.55^{\star \star \star} \\
(4.86)\end{array}$ & $\begin{array}{l}0.57^{\star \star \star} \\
(4.70)\end{array}$ & $\begin{array}{l}0.60^{\star \star \star \star} \\
(4.24)\end{array}$ \\
\hline G2 Southeast Asia & $\begin{array}{l}0.78^{\star \star} \\
(2.45)\end{array}$ & $\begin{array}{l}0.81^{\star \star} \\
(2.03)\end{array}$ & $\begin{array}{r}0.82^{\star} \\
(1.91)\end{array}$ & $\begin{array}{c}0.90 \\
(1.07)\end{array}$ & $\begin{array}{l}0.64^{\star \star \star} \\
(3.56)\end{array}$ & $\begin{array}{l}0.64^{\star \star \star} \\
(3.58)\end{array}$ & $\begin{array}{l}0.65^{\star \star \star} \\
(3.52)\end{array}$ & $\begin{array}{l}0.68^{\star \star \star} \\
(3.16)\end{array}$ \\
\hline G2 Turkey & $\begin{array}{l}0.21^{\star \star \star} \\
(6.88)\end{array}$ & $\begin{array}{l}0.23^{\star \star \star} \\
(6.37)\end{array}$ & $\begin{array}{l}0.23^{\star * *} \\
(6.45)\end{array}$ & $\begin{array}{l}0.22^{\star \star \star} \\
(6.59)\end{array}$ & $\begin{array}{l}0.35^{\star \star \star} \\
(5.19)\end{array}$ & $\begin{array}{l}0.42^{\star \star \star} \\
(4.26)\end{array}$ & $\begin{array}{l}0.42^{\star \star \star} \\
(4.29)\end{array}$ & $\begin{array}{l}0.42^{\star \star \star \star} \\
(4.32)\end{array}$ \\
\hline G2 Southern Europe & $\begin{array}{l}0.83^{\star \star \star} \\
(4.05)\end{array}$ & $\begin{array}{l}0.83^{\star \star \star} \\
(3.74)\end{array}$ & $\begin{array}{l}0.83^{\star \star \star} \\
(3.92)\end{array}$ & $\begin{array}{l}0.81^{\star \star \star} \\
(4.31)\end{array}$ & $\begin{array}{c}0.97 \\
(0.68)\end{array}$ & $\begin{array}{c}1.01 \\
(0.24)\end{array}$ & $\begin{array}{c}1.02 \\
(0.39)\end{array}$ & $\begin{array}{c}0.99 \\
(0.18)\end{array}$ \\
\hline
\end{tabular}

${ }^{\star} p<0.1 ;{ }^{* \star} p<0.05 ; * \star{ }^{*} \mathrm{p}<0.01$

Source: Calculations based on Trajectories and Origins survey (TeO), INED-INSEE, 2008

Coverage: Immigrants aged 18-60 who arrived single in metropolitan France, Native French aged 18-60, and descendants of immigrants aged 18-50. Robust $z$ statistics in parentheses. TV: time-varying variable.

Model 1: controlled for origin, cohort, age, child conception.

Model 2: additionally controlled for social background and religiosity.

Model 3: additionally controlled for educational level.

Model 4: additionally controlled for being in education and in stable employment. 
Taking into account socio-economic and cultural background (Model 2) diminishes the direct marriage gap between immigrants and their descendants versus the native French. Direct marriage appears to be clearly linked with lower social background and greater importance of religion, especially regarding Turkish immigrants and their descendants. Controlling for educational level (Model 3) also decreases the risk of immigrants marrying directly and, to a lesser extent, their descendants; but it does not affect their timing of cohabitation. Conversely, when time-varying variables related to end of schooling and access to stable employment are added (Model 4), the risk of direct marriage increases for immigrants, except for those from Southern Europe. This is a sign that timing of marriage is related to professional integration. However, differences in socio-economic and cultural background and in educational level and employment path do not remove the differences between immigrants, their descendants, and the native French, especially among Turkish immigrants. Controlling for such variables only marginally affects the timing of cohabitation. The likelihood of cohabitation increases slightly for second-generation immigrants once religiosity and social background are controlled for (Model 2), but the gap compared to natives remains.

Separate models by origin (Table 8) show that religiosity, educational attainment, and access to stable employment have different effects on the transition to cohabitation according to origin. As expected, religiosity has a significant effect for those from a Muslim culture. Hence, immigrant men and women from Turkey and female immigrants from the Maghreb (for whom religion was important during childhood) have a significantly lower risk of cohabiting. This also holds true for the second generations from the Maghreb. Likewise, the likelihood of cohabitation is higher for male immigrants from Southeast Asia and Southern Europe, and for male descendants of Sub-Saharan Africa with low religiosity. ${ }^{11}$

\footnotetext{
${ }^{11}$ Low religiosity decreases the risk of both cohabitation and direct marriage (results not shown here and given upon request).
} 
Table 8: $\quad$ Relative risk of cohabiting union, by origin

\begin{tabular}{|c|c|c|c|c|c|c|c|c|c|c|c|}
\hline & $\begin{array}{c}\text { G1 } \\
\text { Maghreb }\end{array}$ & $\begin{array}{c}\text { G1 } \\
\text { Africa }\end{array}$ & $\begin{array}{c}\text { G1 } \\
\text { SEA }\end{array}$ & $\begin{array}{c}\text { G1 } \\
\text { Turkey }\end{array}$ & $\begin{array}{c}\text { G1 } \\
\text { South } \\
\text { Europe }\end{array}$ & $\begin{array}{c}\text { G2 } \\
\text { Maghreb }\end{array}$ & $\begin{array}{c}\text { G2 } \\
\text { Africa }\end{array}$ & G2 SEA & $\begin{array}{c}\text { G2 } \\
\text { Turkey }\end{array}$ & $\begin{array}{c}\text { G2 } \\
\text { South } \\
\text { Europe }\end{array}$ & Native \\
\hline \multicolumn{12}{|l|}{ Women } \\
\hline $\begin{array}{l}\text { Religion not } \\
\text { important }\end{array}$ & $0.52^{\star}$ & 0.97 & 1.44 & 0.51 & 1.37 & 1.17 & 0.78 & 0.80 & 0.47 & 1.16 & $1.22^{\star \star \star}$ \\
\hline $\begin{array}{l}\text { Religion } \\
\text { rather } \\
\text { important }\end{array}$ & $0.62^{\star}$ & 0.72 & 1.34 & 0.52 & 0.98 & $0.63^{\star \star \star}$ & 0.93 & 0.71 & 0.41 & 1.13 & 1.05 \\
\hline $\begin{array}{l}\text { Religion } \\
\text { very } \\
\text { important }\end{array}$ & $0.58^{\star \star}$ & 0.92 & 1.16 & $0.30^{*}$ & 1.02 & $0.53^{\star \star \star}$ & 0.71 & 1.00 & 0.67 & 1.10 & 0.86 \\
\hline $\begin{array}{l}\text { Professional } \\
\text { education }\end{array}$ & 0.67 & 1.43 & 0.73 & 1.50 & $1.50^{\star \star}$ & 0.93 & 1.11 & 0.69 & 1.56 & 1.17 & $1.46^{\star \star \star}$ \\
\hline $\begin{array}{l}\text { Secondary } \\
\text { education }\end{array}$ & 0.62 & 1.23 & 1.10 & 1.80 & 1.01 & 0.99 & 1.05 & 0.57 & 2.49 & $1.42^{\star \star \star}$ & $1.44^{\star \star *}$ \\
\hline $\begin{array}{l}\text { Tertiary } \\
\text { education }\end{array}$ & 1.09 & $1.54^{\star}$ & 0.72 & 1.18 & $2.05^{\star \star \star}$ & 1.19 & 1.23 & 0.78 & 2.91 & $1.43^{\star \star \star}$ & $1.72^{\star \star \star}$ \\
\hline In education & $0.57^{*}$ & $0.58^{\star \star}$ & 0.98 & 0.75 & $0.18^{\star \star \star}$ & $0.45^{\star \star \star}$ & 0.67 & $0.47^{\star \star}$ & 0.38 & $0.49^{\star \star \star}$ & $0.50^{\star \star \star}$ \\
\hline $\begin{array}{l}\text { Stable } \\
\text { employment }\end{array}$ & $1.49^{\star}$ & 1.30 & 1.44 & 2.25 & 0.99 & $1.55^{\star \star \star}$ & 1.64 & $2.38^{\star \star \star}$ & 1.48 & $1.76^{\star \star \star}$ & $2.21^{\star \star \star}$ \\
\hline$N$ & 1,550 & 961 & 771 & 465 & 1,512 & 4,257 & 1,136 & 680 & 582 & 4,422 & 6,397 \\
\hline \multicolumn{12}{|l|}{ Men } \\
\hline $\begin{array}{l}\text { Religion not } \\
\text { important }\end{array}$ & 1.10 & 0.76 & $1.52^{\star}$ & 1.59 & 0.99 & 1.05 & $0.46^{\star \star}$ & 1.39 & 2.00 & $0.86^{\star}$ & $1.16^{\star \star}$ \\
\hline $\begin{array}{l}\text { Religion } \\
\text { rather } \\
\text { important }\end{array}$ & 0.90 & 1.17 & 1.20 & 0.71 & 0.92 & 0.99 & $0.39^{\star \star \star}$ & 0.73 & 1.72 & $0.83^{\star}$ & $0.84^{\star}$ \\
\hline $\begin{array}{l}\text { Religion } \\
\text { very } \\
\text { important }\end{array}$ & 0.78 & 1.01 & 0.73 & $0.36^{\star \star}$ & 1.09 & $0.45^{\star \star \star}$ & $0.45^{\star \star}$ & 0.64 & 3.06 & 0.83 & $0.63^{\star \star *}$ \\
\hline $\begin{array}{l}\text { Professional } \\
\text { education }\end{array}$ & 1.08 & 1.10 & 1.22 & 1.15 & 0.92 & 1.17 & 1.36 & $3.50^{\star \star}$ & 0.69 & $1.40^{\star \star \star}$ & $1.25^{\star \star}$ \\
\hline $\begin{array}{l}\text { Secondary } \\
\text { education }\end{array}$ & $1.66^{\star \star}$ & 1.35 & 1.24 & 1.22 & 1.36 & 0.90 & 1.68 & 1.37 & 0.92 & 1.05 & $1.35^{\star \star \star}$ \\
\hline $\begin{array}{l}\text { Tertiary } \\
\text { education }\end{array}$ & $1.46^{\star}$ & $1.69^{\star \star}$ & 1.37 & 1.70 & 0.97 & 1.11 & 1.31 & $2.75^{\star \star}$ & 1.18 & $1.58^{\star \star \star}$ & $1.63^{\star \star \star}$ \\
\hline In education & 0.79 & 0.87 & 0.62 & 0.68 & $0.32^{\star \star \star}$ & $0.51^{\star \star \star}$ & 0.58 & 0.60 & 1.66 & $0.56^{\star \star \star}$ & $0.55^{\star \star \star}$ \\
\hline $\begin{array}{l}\text { Stable } \\
\text { employment }\end{array}$ & 0.74 & 1.19 & 0.79 & $2.28^{\star \star \star}$ & 0.81 & $1.67^{\star \star \star *}$ & 1.48 & 1.76 & 2.15 & $2.27^{\star \star \star}$ & $2.51^{\star \star *}$ \\
\hline$N$ & 2,231 & 1,083 & 1,274 & 760 & 1,828 & 3,656 & 1,015 & 790 & 613 & 4,788 & 6,342 \\
\hline
\end{tabular}

${ }^{\star} \mathrm{p}<0.1 ;{ }^{\star \star} \mathrm{p}<0.05 ;{ }^{\star \star \star} \mathrm{p}<0.01$

Controlled for cohort, age, child conception, and social background

In line with our third hypothesis, the risk of cohabitation generally increases with educational attainment, given that it favors distancing oneself from parental norms. However, the effect is not significant for all groups. In particular, for second generations, having a higher education level does not appear to significantly increase the risk of cohabitation, except for second generations from Southern Europe. The models by origin may lack the statistical power to detect the effect. 
This positive but non-significant effect may also be related to the fact that many second generations who are still in tertiary education wait until they have completed their schooling and found a stable job before entering a union. Individuals with higher education may also wait longer before entering a consensual union because their contact with a greater number of potential partners means that they take more time to consider their options before settling down. They may also wait until they have gained some degree of independence from their parents before starting to cohabit, especially if their parents have low economic resources. Access to selfsufficiency through stable employment increases the risk of cohabitation, especially for the second generation. Hence, gaining stable employment significantly increases the risk of entering into cohabitation for second-generation men and women from the Maghreb and Southern Europe, and for female descendants of immigrants from Southeast Asia.

\subsection{The transition from cohabitation to marriage}

Turkish immigrants not only have a higher propensity to marry directly, but also a higher propensity to marry after having cohabited (Table 9). Transitions from cohabitation to marriage are also significantly higher for immigrants from North Africa compared to the native French. We do not find such an effect for male immigrants from the Maghreb once socio-cultural background is taken into consideration. Immigrant women from Southern Europe also have a higher probability of turning cohabitation into marriage.

The pattern is rather different for second-generation immigrants. Indeed, the risk of marrying after having cohabited is not significantly different compared to the native French, except for female descendants of Turkish immigrants, who have much lower chances of marrying. In other words, those few women born of Turkish ancestry who have not adopted the dominant formation type in their origin group (i.e., direct marriage) have a low probability of converting their consensual union into marriage. For them, entering cohabitation seems to be an alternative to marriage rather than a way of delaying it. The other descendants of immigrants who start union formation by cohabitation have the same behavior as the native French, i.e., a rather low transition from cohabitation to marriage. However, Southeast Asian second-generation men have a higher probability of marrying after cohabitation than natives. Cohabitation is less frequent for them, but is more often a stepping-stone to marriage. Again, socio-economic and cultural background matter for immigrants and their descendants, but taking into account these factors does not affect the results so much. 
Table 9: $\quad$ Relative risk of transition from cohabitation to marriage, by country of origin

\begin{tabular}{|c|c|c|c|c|c|c|c|c|}
\hline & \multirow{2}{*}{$\begin{array}{l}\text { Women } \\
\text { Model } 1\end{array}$} & \multicolumn{7}{|c|}{ Men } \\
\hline & & Model 2 & Model 3 & Model 4 & Model 1 & Model 2 & Model 3 & Model 4 \\
\hline$\overline{\mathrm{G} 1}$ & $1.70^{\star \star \star}$ & $1.68^{\star \star \star}$ & $1.72^{\star \star \star}$ & $1.74^{\star \star \star}$ & $1.35^{\star \star}$ & 1.24 & 1.25 & 1.29 \\
\hline Maghreb & (3.35) & (3.09) & (3.13) & (3.13) & $(2.15)$ & $(1.38)$ & $(1.43)$ & (1.62) \\
\hline G1 Africa & $\begin{array}{c}1.07 \\
(0.43)\end{array}$ & $\begin{array}{c}1.23 \\
(1.21)\end{array}$ & $\begin{array}{c}1.27 \\
(1.37)\end{array}$ & $\begin{array}{c}1.27 \\
(1.37)\end{array}$ & $\begin{array}{c}1.25 \\
(1.51)\end{array}$ & $\begin{array}{c}1.06 \\
(0.35)\end{array}$ & $\begin{array}{c}1.01 \\
(0.05)\end{array}$ & $\begin{array}{c}1.02 \\
(0.14)\end{array}$ \\
\hline $\begin{array}{l}\text { G1 } \\
\text { Southeast }\end{array}$ & 1.30 & 1.27 & 1.29 & 1.28 & 1.00 & 0.91 & 0.94 & 0.97 \\
\hline Asia & (1.54) & $(1.36)$ & $(1.46)$ & $(1.41)$ & $(0.00)$ & $(0.45)$ & $(0.32)$ & $(0.16)$ \\
\hline G1 Turkey & $\begin{array}{l}3.34^{\star \star \star} \\
(3.97)\end{array}$ & $\begin{array}{l}3.09^{\star \star \star} \\
(3.48)\end{array}$ & $\begin{array}{l}3.10^{\star \star \star} \\
(3.41)\end{array}$ & $\begin{array}{l}3.06^{\star \star \star} \\
(3.36)\end{array}$ & $\begin{array}{l}3.05^{\star \star \star} \\
(5.09)\end{array}$ & $\begin{array}{l}2.86^{\star \star \star} \\
(4.80)\end{array}$ & $\begin{array}{l}2.92^{\star \star \star} \\
(4.69)\end{array}$ & $\begin{array}{l}3.00^{\star \star \star} \\
(4.80)\end{array}$ \\
\hline $\begin{array}{l}\text { G1 } \\
\text { Southern }\end{array}$ & $1.37^{\star \star}$ & $1.33^{\star \star}$ & $1.37^{\star \star}$ & $1.39^{\star *}$ & 1.10 & 1.06 & 1.13 & 1.15 \\
\hline Europe & (2.52) & (2.09) & $(2.20)$ & $(2.28)$ & $(0.74)$ & $(0.39)$ & $(0.86)$ & $(0.93)$ \\
\hline G2 & 0.98 & 0.95 & 0.97 & 0.97 & 0.90 & 0.92 & 0.96 & 0.98 \\
\hline Maghreb & $(0.18)$ & $(0.42)$ & $(0.29)$ & $(0.25)$ & $(0.82)$ & $(0.64)$ & $(0.28)$ & $(0.19)$ \\
\hline G2 Africa & $\begin{array}{c}0.70 \\
(1.53)\end{array}$ & $\begin{array}{c}0.73 \\
(1.33)\end{array}$ & $\begin{array}{c}0.73 \\
(1.36)\end{array}$ & $\begin{array}{c}0.73 \\
(1.36)\end{array}$ & $\begin{array}{c}1.44 \\
(0.83)\end{array}$ & $\begin{array}{c}1.36 \\
(0.75)\end{array}$ & $\begin{array}{c}1.42 \\
(0.80)\end{array}$ & $\begin{array}{c}1.39 \\
(0.77)\end{array}$ \\
\hline $\begin{array}{l}\text { G2 } \\
\text { Southeast } \\
\text { Asia }\end{array}$ & 1.27 & 1.35 & 1.36 & 1.35 & $1.49^{\star \star}$ & $1.54^{\star \star}$ & $1.47^{\star \star}$ & $1.47^{\star \star}$ \\
\hline & $(0.96)$ & (1.24) & (1.28) & (1.24) & $(2.30)$ & $(2.41)$ & $(2.03)$ & $(2.05)$ \\
\hline G2 Turkey & $\begin{array}{l}0.05^{\star \star \star} \\
(2.86)\end{array}$ & $\begin{array}{l}0.05^{\star \star \star} \\
(2.78)\end{array}$ & $\begin{array}{l}0.05^{\star \star \star} \\
(2.77)\end{array}$ & $\begin{array}{l}0.05^{\star \star \star} \\
(2.77)\end{array}$ & $\begin{array}{c}0.65 \\
(0.91)\end{array}$ & $\begin{array}{c}0.54 \\
(1.26)\end{array}$ & $\begin{array}{c}0.51 \\
(1.32)\end{array}$ & $\begin{array}{c}0.52 \\
(1.30)\end{array}$ \\
\hline G2 & 1.03 & 1.00 & 1.00 & 1.00 & 0.78 & 0.80 & 0.82 & 0.83 \\
\hline $\begin{array}{l}\text { Southern } \\
\text { Europe }\end{array}$ & $(0.24)$ & $(0.03)$ & (0.01) & $(0.01)$ & $(1.49)$ & $(1.42)$ & $(1.31)$ & (1.31) \\
\hline
\end{tabular}

${ }^{\star} p<0.1 ; * \star p<0.05 ; * \star{ }^{*} p<0.01$

Source: Calculations based on Trajectories and Origins survey (TeO), INED-INSEE, 2008

Coverage: Immigrants aged 18-60 who arrived single in metropolitan France, Native French aged 18-60, and descendants of immigrants aged $18-50$.

Model 1: controlled for origin, cohort, duration of cohabitation, age at cohabitation, child conception.

Model 2: additionally controlled for social background and religiosity.

Model 3: additionally controlled for educational level.

Model 4: additionally controlled for being in education and in stable employment.

Robust $z$ statistics in parentheses

TV: time-varying variable 


\section{Conclusion and discussion}

This study has investigated transformations in partnership formation, i.e., the timing and type of first union across generations of immigrants pertaining to the main origin groups in France. It has analyzed men and women separately, using data from the Trajectories and Origin survey. It addressed how the socialization vs. assimilation hypothesis shapes immigrants and their descendants' first partnership formation patterns, analyzing the interplay of cultural and structural factors by focusing on religiosity, education, and access to employment.

In line with our first hypothesis, we find there are significant differences in partnership trajectories between the first and the second generations. First of all, both male and female second-generation immigrants form their first union later than the first generation. The adaptation process of partnership patterns over generations also manifests with lower levels of direct marriage over generations, while the level of informal cohabitation increases. The development of pre-marital cohabitation over generations of immigration is a sign of more gradual entry into a union and an alternative way of living: descendants of immigrants have more choices than their parents regarding lifestyle and personal arrangements, and they have more freedom to plan their own lives. It also signals a weakening of traditional family behaviors, in particular regarding changes in the conception of pre-marital sex.

This convergence towards prevailing French behavior varies across origins. It is higher for immigrants coming from societies whose cultural standards are close to those of France, which supports our second hypothesis. In particular, descendants of immigrants from Southern Europe have partnership behaviors similar to those of the native French, especially regarding pre-marital cohabitation. Conversely, convergence is lower for those who come from countries where direct marriage is frequent and the norms concerning virginity at marriage are strict. Hence, male and female Turkish immigrants and their descendants follow the traditional Turkish pattern of early marriage. As was found earlier for France (Milewski and Hamel 2010) and for other European countries (de Valk 2006; Lievens 1999; Soehl and Yahirun 2011; Bernardt et al. 2007), they enter into their first union quite early compared to those of other origins, even if they postpone entry into direct marriage relative to first-generation immigrants. Although the Turkish second generation appears to be open to modern values regarding cohabitation (Streiff-Fénart 2006; Collet and Santelli 2012), they still tend to marry directly rather than entering cohabitation. In this respect they reproduce their parents' behaviors. This is a reflection of Turkish descendants of immigrants sharing parental traditions (in particular the importance of virginity at marriage) and of them being influenced by their parents in partnership formation (Milewski and Hamel 2010). It may also be 
related to the high rate of endogamous marriages between second- and firstgeneration Turkish immigrants (Hamel et al. 2015). In this case, as for immigrants, restrictive immigration policy promotes high rates of direct marriage, given that family reunification is the main legal way for people to move to France.

The institution of marriage also remains important for immigrants from the Maghreb and, to a lesser extent, their descendants. The tempo of change between the first and second generations is, however, more marked for Maghrebis than for Turks. Thus, among those of Muslim descent, there is a higher convergence for the earliest immigration flows. However, to qualify our earlier conclusions, the process of convergence towards French behaviors is also pronounced for some groups whose sending country's marital norms radically differ from French standards. Children of Southeast Asian and Sub-Saharan African immigrants postpone union formation and have low likelihood of direct marriage.

These cross-origin differences are partly related to socio-cultural background. As expected (hypothesis H2b), low levels of parental socioeconomic status and strong religious commitment are associated with earlier entry into union and more direct marriage. But the introduction of such explanatory factors in the models only slightly reduces origin differences in the propensity for direct marriage and in the timing of first union. Similarly, in spite of the fact that education drives the decline in direct marriage and increase in cohabitation, cross-origin differences in the type of first union are only slightly explained by differences in education level. Increasing level of education does not appear to significantly increase the risk of cohabitation for second generations, which is contrary to our H3 hypothesis. It thus appears that education has less effect on behaviors than on preferences regarding partnership formation (Huschek, Liefbroer and de Valk 2010; Bernardt et al. 2007). Access to self-sufficiency through stable employment also has a positive effect on partnership formation. Nevertheless, taking into account different tempos of access to stable employment does not eliminate the differences across groups, and it does not explain the postponement of first union among the second generation, which was unexpected $(\mathrm{H} 4)$.

As assumed (H5), the analysis shows differences by gender regarding partnership behaviors. Women in all groups enter into partnership earlier than men, and they marry more directly. But, relative to natives, women of the second generation postpone first union formation more than men, which signals a change in women's roles over generations. Once control factors are taken into account (especially socio-cultural background), the gap with regards to natives is higher for men than for women in terms of the timing of first union and especially of direct marriage. Thus, parents' religious commitment still significantly affects access to autonomy for women. Education and access to employment have lower effects. 
Finally, structural factors like higher level of education have led to changes in partnership formation patterns over generations of immigration, but the convergence is not complete, and cultural factors (i.e., socialization) have a strong effect, especially for women. Wide cross-origin variations were found in the timing of partnership formation, independently of the individuals' family and socioeconomic background characteristics. The second generation still diverges from the dominant French norm of the unmarried couple by postponing union formation. It appears that practices regarding type of union are not so easy to give up. The postponement of union formation may be related to how immigrants and second-generation immigrants think a union should be, i.e., a long-term engagement rather than a trial period. Changes in behavior take time. It took several generations for cohabitation to diffuse in European countries, and not surprisingly it will take time for immigrants' descendants to adopt such behavior (Glick et al. 2006).

Given that the population of immigrants under study is selected, we certainly over-estimate the adaptation of partnership behaviors among the immigrants. Individuals who are single upon arriving migrate on their own initiative, either to find work or to pursue their education (Beauchemin, Borrel, and Régnard 2015). They may adapt more readily to the partnership practices of the settlement country. If so, we certainly underestimate the descendants of immigrants' adaptation by comparing the first and the second generations. To check this selection effect, we ran the same estimations over a sample that includes immigrants who entered a partnership before migration ${ }^{12}$. The comparison of results confirms our expectations. For female immigrants from Turkey and Sub-Saharan Africa, differences with regard to natives are slightly larger when all immigrants are considered. The effect of selection is higher for men, especially for African immigrants. When all immigrants are considered, male immigrants from SubSaharan Africa form their first union later than native French men - but earlier for those who migrate after forming a union. Apart from this case, the selection has little effect and, as expected, when all immigrants are taken into account the adaptation of all immigrants is lower, and that of descendants of immigrants compared to immigrants is higher.

Another limitation of this study is that we do not take into account all structural factors that shape the timing of union formation. In particular, we imperfectly take into account their economic situation, whereas the level of income explains the timing of leaving the parental home and partnership formation (Smock and Manning 1997; Oppenheimer 1988). Local socio-economic conditions must also be taken into account, since living in degraded and segregated areas reduces contact with the mainstream population, and this can also influence partnership

\footnotetext{
${ }^{12}$ Results not shown here and given upon request.
} 
formation. Longer transition to partnership formation may also be related to specific challenges for the second generation: they have to find a partner that suits them and who matches their parents' aspirations, which may take longer to find. In particular, exogamous unions tend to occur later than endogamous unions (Soehl and Yahirun 2011). Future research should take into account how the dominant norm for endogamous marriage shapes union formation.

\section{Acknowledgements}

I am grateful for comments and suggestions from Hill Kulu, Tina Hanneman, Emmanuelle Santelli, and the two anonymous reviewers. The research leading to these results has received funding from the European Union's Seventh Framework Programme (FP7/2007-2013), under grant agreement no. 320116 for the research project FamiliesAndSocieties. 


\section{References}

Adserà, A. and Ferrer, A. (2014). Immigrants and Demography: Marriage, Divorce, and Fertility. In: Chiswick, B.R. and Miller, P.W. (eds.). Handbook on the Economics of International Migration. Elsevier.

Alba, R. and Nee, V. (2003). Remaking the American mainstream: assimilation and contemporary immigration. Cambridge: Harvard University Press. doi:10.4159/9780674020115.

Algan, Y., Bisin, A., Manning, A., and Verdier, T. (2012). Cultural Integration of Immigrants in Europe (Studies of Policy Reform). UK: Oxford University Press. doi:10.1093/acprof:oso/9780199660094.001.0001.

Andersson, G. (2004). Childbearing after migration: Fertility patterns of foreignborn women in Sweden. International Migration Review 38(2): 747-774. doi:10.1111/j.1747-7379.2004.tb00216.x.

Andro, A. (2012). Young People Who Have Not Yet Had Sexual Intercourse: Social Norms and Lack of Opportunity. In: Bajos, N. and Bozon, M. (eds.). Sexuality in France: Gender Practices and Health. The Bardwell Press.

Arias, E. (2001). Change in Nuptiality Patterns among Cuban Americans: Evidence of Cultural and Structural Assimilation?. International Migration Review 35(2): 525-556. doi:10.1111/j.1747-7379.2001.tb00028.x.

Axinn, W.G. and Thornton, A. (1992). The influence of parental resources on the timing of the transition to marriage. Social Science Research 21(3): 261285. doi:10.1016/0049-089X(92)90008-5.

Beauchemin, C., Hamel, Ch., and Simon, P. (2010). Trajectories and Origins: Survey on Population Diversity in France. Document de travail de l'Ined.

Beauchemin, C., Borrel, C., and Régnard, C. (2015). Le renouveau des migrations féminines. In: Beauchemin, C., Hamel, Ch., and Simon, P. (eds.). Enquête Trajectoires et origines. Paris: Ined.

Bernhardt, E., Goldscheider, F., Goldscheider, C., and Bjerén, G. (2007). Entering adulthood in Sweden: Gender, family and immigrant origins. Stockholm: Centre for Gender studies Stockholm University.

Billari, F.C. and Liefbroer, A.C. (2010). Towards a new pattern of transition to adulthood? Advances in Life Course Research 15(2-3): 59-75. doi:10.1016/ j.alcr.2010.10.003. 
Blossfeld, H.P. and Huinink, J. (1991). Human Capital Investments or Norms of Role Transition? How Women's Schooling and Career Affect the Process of Family Formation. American Journal of Sociology 97(1): 143-168. doi:10.1086/229743.

Blossfeld, H-P., Klijzing, E., Mills, M., and Kurz, K. (2005). Globalization, Uncertainty and Youth in Society. Routledge.

Brouard, S. and Tiberj, V. (2005). Français comme les autres ? Enquête sur les citoyens d'origine maghrébine, africaine et turque. Paris: Presses de Sciences Po.

Brückner, H. and Mayer, K.U. (2005). De-Standardization of the life-course: What it might mean? And if it means anything, whether it actually took place? Advances in Life Course Research 9: 27-54. doi:10.1016/S1040-2608 (04)09002-1.

Buchmann, M.C. and Kriesi, I. (2011). Transition to Adulthood in Europe. Annual Review of Sociology 37(1): 481-503. doi:10.1146/annurev-soc-081309150212.

Charton, L. (2009). Du désir d'enfant à la première et deuxième naissance. In: Regnier-Loilier, A. (eds.). Portraits de familles. Paris: Editions de l'Ined, coll. Grandes enquêtes.

Collet, B. and Santelli, E. (2012). Couples d'ici, parents d'ailleurs. Parcours de descendants d'immigrés. Paris: PUF.

Cortina Trilla, C., Esteve, A., and Domingo, A. (2008). Marriage Patterns of the Foreign-Born Population in a New Country of Immigration: The Case of Spain. International Migration Review 42(4): 877-902. doi:10.1111/j.17477379.2008.00151.x.

Crissey, S.R. (2005). Race/Ethnic Differences in the Marital Expectations of Adolescents: The Role of Romantic Relationships. Journal of Marriage and Family 67(3): 697-709. doi:10.1111/j.1741-3737.2005.00163.x.

De Valk, H.A.G. (2006). Pathways into adulthood - A comparative study on family life transitions among migrant and Dutch youth. [PhD thesis]. Utrecht: Universiteit Utrecht, Sociology Department. 
De Valk, H.A.G. and Liefbroer, A. (2007). Timing preferences for women's familylife transitions: Intergenerational transmission among migrants and Dutch. Journal of Marriage and Family 69:190-206. doi:10.1111/j.1741-3737. 2006.00353.x.

De Valk, H.A.G. and Milewski, N. (2011). Family life transitions among children of immigrants: an introduction. Advances in Life Course Research 16:145151. doi:10.1016/j.alcr.2011.10.001.

Diehl, C., Koenig, M., and Ruckdeschel, K. (2009). Religiosity and gender equality: comparing natives and Muslim migrants in Germany. Ethnic and Racial Studies 32(2): 278-301. doi:10.1080/01419870802298454.

East, P.L. (1998). Racial and Ethnic Differences in Girls' Sexual, Marital, and Birth Expectations. Journal of marriage and the family 60(1):150-162. doi:10.2307/353448.

Favell, A. (2001). Philosophies of Integration: Immigration and the Idea of Citizenship in France and Britain (2nd ed.). London: Macmillan. doi:10.1057/9780333992678.

Foner, N. (1997). The Immigrant Family: Cultural Legacies and Cultural Changes. International Migration Review 31(4): 961-974. doi:10.2307/2547420.

Furtado, D. (2012). Human capital and interethnic marriage decisions. Economic Inquiry 50(1): 82-93. doi:10.1111/j.1465-7295.2010.00345.x.

Glick, J.E. (2010). Connecting Complex Processes: A Decade of Research on Immigrant Families. Journal of Marriage and Family 72(3): 498-515. doi:10.1111/j.1741-3737.2010.00715.x.

Glick, J.E., Ruf, S.D., White, M.J., and Goldscheider, F. (2006). Educational Engagement and Early Family Formation: Differences by Ethnicity and Generation. Social Forces 84(3): 1391-1415. doi:10.1353/sof.2006.0049.

Gordon, M.M. (1964). Assimilation in American Life: The Role of Race, Religion and National Origins. New York: Oxford University Press.

Hamel, Ch., Huschek, D., Milewski, N., and de Valk, H. (2012). Union formation and partner choice. In: Crul, M., Schneider, J., and Lelie, F. (eds.). The European second generation compared: does the integration context matter? Amsterdam: Amsterdam University Press. 
Hamel, C., Lhommeau, B., Pailhé, A., and Santelli, E. (2015). Rencontrer son conjoint dans un espace multiculturel et international. In: Beauchemin, C., Hamel, Ch., and Simon, P. (eds.). Enquête Trajectoires et origines. Paris: Collection Grandes enquêtes, Ined, forthcoming.

Hamel, Ch., Moguérou, L., and Santelli, E. (2011). L’entrée dans la vie adulte des filles et fils d'immigrés. Politiques sociales et familiales 105: 47-58.

Hervitz, H.M. (1985). Selectivity, adaptation, or disruption? A comparison of alternative hypotheses on the effects of migration on fertility: The case of Brazil. International Migration Review 19(2): 293-317. doi:10.2307/ 2545774.

Huschek, D., de Valk, H.A.G., and Liefbroer, A.C. (2011). Does social embeddedness influence union formation differences among the Turkish and Moroccan generation in the Netherlands?. Journal of Comparative Family Studies 42(6): 787-808.

Huschek, D., Liefbroer, A.C., and de Valk, H.A.G. (2010). Timing of first union among second generation Turks in Europe: The role of parents, peers and institutional context. Demographic Research 22(16): 473-504. doi:10.4054/ DemRes.2010.22.16.

Huschek, D., Liefbroer, A.C., and de Valk, H.A.G. (2011). Gender-role behavior of second-generation Turks: The role of partner choice, gender ideology and societal context. Advances in Life Course Research 16(4): 164-177. doi:10.1016/j.alcr.2011.09.005.

Huschek, D., Liefbroer, A.C., and de Valk, H.A.G. (2012). Partner Choice Patterns Among the Descendants of Turkish Immigrants in Europe. European Journal of Population / Revue européenne de Démographie 28(3): 241-268.

Insee (2012). Immigrés et descendants d'immigrés en France. Insee, Coll Insee Références.

Idema, H. and K. Phalet (2007). Transmission of Gender-Role Values in TurkishGerman Migrant Families: The Role of Gender, Intergenerational and Intercultural Relations. Zeitschrift für Familienforschung 19(1): 71-105.

Kalmijn, M. (1998). Intermarriage and homogamy: causes, patterns, trends. Annual review of Sociology 24: 395-421. doi:10.1146/annurev.soc.24.1.395. 
Kalmijn, M. and van Tubergen, F. (2006). Ethnic Intermarriage in the Netherlands: Confirmations and Refutations of Accepted Insights. European Journal of Population 22: 371-397. doi:10.1007/s10680-006-9105-3.

Kofman, E. (2004). Family-related migration: a critical review of European Studies. Journal of Ethnic and Migration Studies 30(2): 243-262. doi:10.1080/ 1369183042000200687.

Koopmans, R. (2010). Trade-Offs between Equality and Difference: Immigrant Integration, Multiculturalism and the Welfare State in Cross-National Perspective. Journal of Ethnic and Migration Studies 36(1): 1-26. doi:10.1080/13691830903250881.

Kulu, H., Rahnu, L., Puur, A., Sakeus, L., Klesment, M., Pailhé, A., Guarin, A., and Bernardi, L. (2014). Country-specific case Studies on partnership dynamics among immigrants and their descendants. FamiliesAndSociety working paper 13.

Kulu, H. and González-Ferrer, A. (2014). Family Dynamics among Immigrants and their Descendants in Europe: Current Research and Opportunities. European Journal of Population 30(4): 411-435. doi:10.1007/s10680-014-9322-0.

Lesthaeghe, R. (1995). The Second Demographic Transition in Western Countries: An Interpretation. In: Oppenheim Mason, K. and Jensen, A.-M. (ed.). Gender and Family Change in Industrialized Countries. Oxford: Clarendon Press: $17-62$.

Lesthaeghe, R. (2010). The Unfolding Story of the Second Demographic Transition. Population and Development Review 36(2): 211-251. doi:10.1111/j.17284457.2010.00328.x.

Lesthaeghe, R.J., and Surkyn, J. (2004). Value Orientations and the Second Demographic Transition (SDT) in Northern, Western and Southern Europe: An Update. Demographic Research 3: 45-86.

Lesthaeghe, R. and Surkyn, J. (1995). Heterogeneity in social change: Turkish and Moroccan women in Belgium. European Journal of Population 11(1): 1-29. doi:10.1007/BF01264103.

Lievens, J. (1999). Family-forming migration from Turkey and Morocco to Belgium: the demand for marriage partners from the countries of origin. International Migration Review 33(3): 717-44. doi:10.2307/2547532. 
Lloyd, K.M. (2006). Latinas Transition to First Marriage: An Examination of Four Theoretical Perspectives. Journal of Marriage and Family 68(4): 993-1014. doi:10.1111/j.1741-3737.2006.00309.x.

Mazuy, M., Barbieri, M., and d'Albis, H. (2013). Recent Demographic Trends in France: Fertility Remains Stable. Population 68(3): 329-374.

Meurs D., Pailhé A., and Simon P. (2006). The Persistence of Intergenerational Inequalities linked to Immigration: Labour Market Outcomes for Immigrants and their Descendants in France. Population - E: English edition 61(5/6): 645-682. doi:10.3917/pope.605.0645.

Michaël, R.T. and Tuma, N.B. (1985). Entry into Marriage and Parenthood by Young Men and Women: The Influence of Family Background. Demography 22(4): 515-544. doi:10.2307/2061586.

Milewski, N. (2007). First child of immigrant workers and their descendants in West Germany: Interrelation of events, disruption, or adaptation?. Demographic Research 17(29): 859-896. doi:10.4054/DemRes.2007.17.29.

Milewski, N. and Hamel, Ch. (2010). Union Formation and Partner Choice in a Transnational Context: The Case of Descendants of Turkish Immigrants in France. International Migration Review 44(3): 615-658. doi:10.1111/j.17477379.2010.00820.x.

Ní Bhrolcháin, M. and Beaujouan, É. (2012). Fertility postponement is largely due to rising educational enrolment. Population Studies 66(3): 311-327. doi:10.1080/00324728.2012.697569.

Noiriel, G. (2006). Le Creuset français: Histoire de l'immigration XIXe-XXe siècle. Paris: édition Poche (1ère édition Seuil 1988).

Oppenheim Mason, K. and Jensen, A-M. (1995). Gender and Family Change in Industrialized Countries. Oxford: Clarendon Press.

Oppenheimer, V.K. (1988). A Theory of Marriage Timing. American Journal of Sociology 94(3): 563-591. doi:10.1086/229030.

Pailhé, A. and Hamel, Ch. (2015). Avoir des enfants en contexte migratoire. In: Beauchemin, C., Hamel, Ch., and Simon, P. (eds.). Enquête Trajectoires et origines. Paris: Collection Grandes enquêtes, Ined, forthcoming. 
Pailhé, A., Mortelmans, D., Castro, T., Cortina Trilla, T., Digoix, M., Festy, P., Krapf, S., Kreyenfeld, M., Lyssens-Danneboom, V., Martín-Garcia, T., Rault, W., Thévenon, O., and Toulemon, L. (2014). Changes in the life course. FamiliesAndSocieties Working paper 6 (2014). http://www.familiesandsocieties.eu/?page_id=131.

Perelli-Harris, B., Kreyenfeld, M., Sigle-Rushton, W., Keizer, R., Lappegård, T., Jasilioniene, A., and Giulio, P. D. (2012). Changes in union status during the transition to parenthood: An examination of 11 European countries. Population Studies 66(2): 167-182. doi:10.1080/00324728.2012.673004.

Portes, A., Fernandez-Kelly, P., and Haller, W. (2009). Segmented assimilation on the ground: The new second generation in early adulthood. Ethnic and racial studies 28(6): 1000-1040. doi:10.1080/01419870500224117.

Portes, A. and Zhou, M. (1993). The new second generation: segmented assimilation and its variants. Annals of the American Academy of Political and Social Science 530(1): 74-96. doi:10.1177/0002716293530001006.

Prioux, F. (2005). Recent Demographic Trends in France. Population 60(4): 371414. doi:10.3917/pope.504.0371.

Prioux, F. (2009). Les couples non mariés en 2005: quelles différences avec les couples mariés?. Politiques sociales et familiales 96: 87-95.

Safi, M. (2008). Intermarriage and Assimilation: disparities in levels of exogamy among immigrants in France. Population 63(2): 239-267. doi:10.3917/pope. 802.0239 .

Sassler, S.L. (1997) Women's marital timing at the turn of the century: Generational and Ethnic Differences. Sociological Quarterly 38(4): 567585. doi:10.1111/j.1533-8525.1997.tb00754.x.

Schnapper, D. (1991). La France de l'intégration. Sociologie de la nation en 1990. Paris: Gallimard.

Schor, R. (1996). Histoire de l'immigration en France de la fin du XIXe siècle à nos jours. Paris: Armand Colin.

Sobotka, T. and Toulemon, L. (2008). Changing family and partnership behavior: Common trends and persistent diversity across Europe. Demographic Research 19(6): 85-138. doi:10.4054/DemRes.2008.19.6. 
Soehl, T. and Yahirun, J. (2011). Timing of union formation and partner choice in immigrant societies: The United States and Germany. Advances in Life Course Research 16(4): 205-216. doi:10.1016/j.alcr.2011.09.004.

South, S.J. (2001). The variable effects of family background on the timing of first marriage: United States, 1969-1993. Social Science Research 30: 606-626. doi:10.1006/ssre.2001.0714.

Smock, P.J. and Manning, W.D. (1997). Cohabiting partners' economic circumstances and marriage. Demography 34(3): 331-341. doi:10.2307/3038 287.

Streiff-Fénart, J. (2006). À propos des valeurs en situation d'immigration: Questions de recherche et bilan des travaux. Revue française de sociologie 47(4): 851875. doi:10.3917/rfs.474.0851.

Tavan, A. (2005) Les calendriers de constitution des familles immigrées. In: Lefèvre, C. and Filhon, A. (eds.). Histoires de familles, histoires familiales. Paris: Les Cahiers de l’Ined, ${ }^{\circ} 156$.

Thiriat, M.-P. (1998). Faire et défaire les liens du mariage. Évolution des pratiques matrimoniales au Togo. Paris: CEPED, 295 p.

Toulemon, L., Pailhé, A., and Rossier, C. (2008). France: High and stable fertility, Childbearing Trends and Policies in Europe. Demographic Research 19(16): 503-556. doi:10.4054/DemRes.2008.19.16.

Tribalat, M. (1996). De l'immigration à l'assimilation. Enquête sur les populations d'origine étrangère en France. Paris: La découverte. 
Pailhé: Partnership dynamics across generations of immigration in France

\section{Appendix 1: Relative risk of direct marriage, by sex}

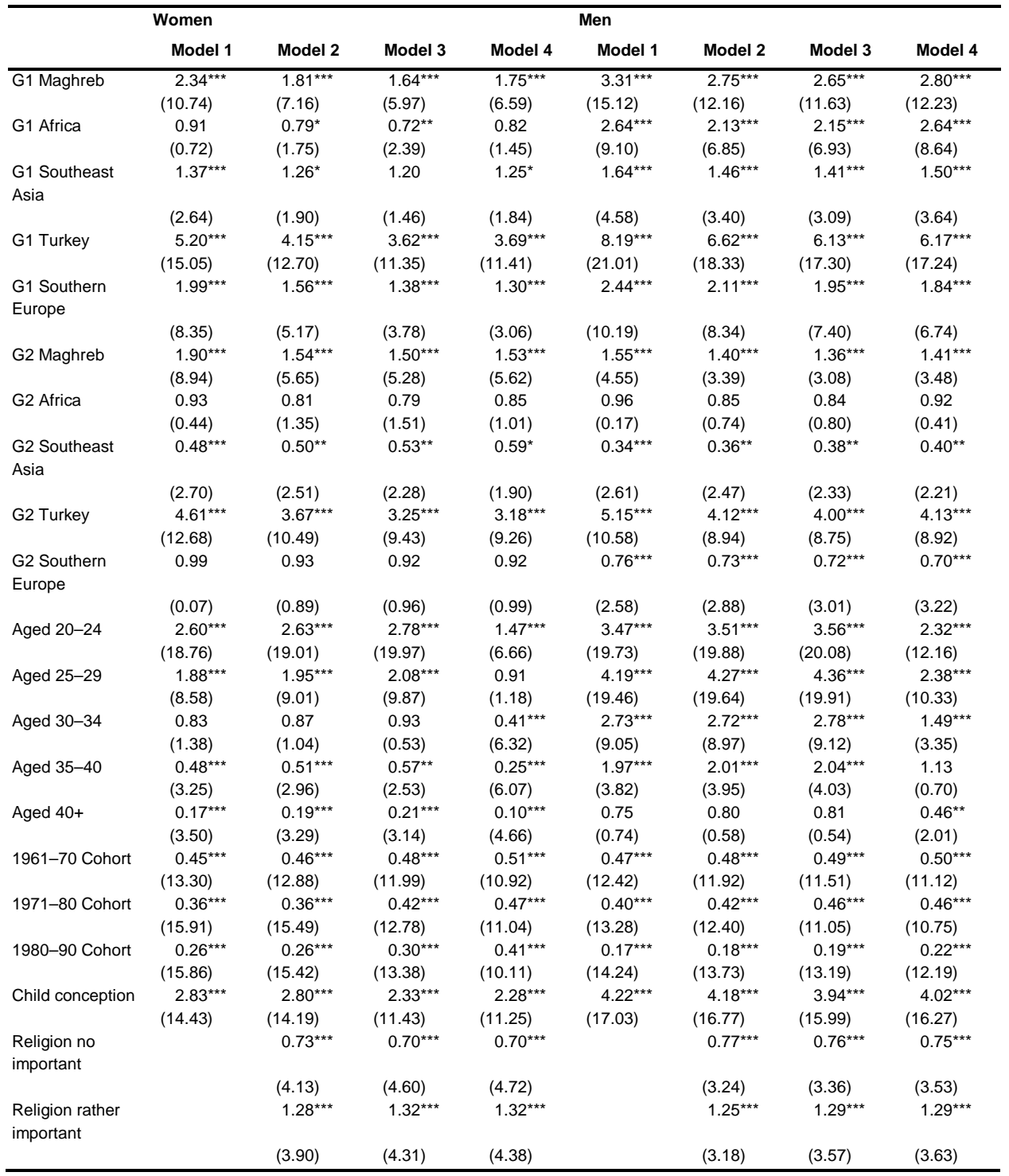




\section{Appendix 1: (Continued)}

\begin{tabular}{|c|c|c|c|c|c|c|c|c|}
\hline & \multicolumn{4}{|l|}{ Women } & \multicolumn{4}{|c|}{ Men } \\
\hline & Model 1 & Model 2 & Model 3 & Model 4 & Model 1 & Model 2 & Model 3 & Model 4 \\
\hline \multirow{2}{*}{$\begin{array}{l}\text { Religion very } \\
\text { important }\end{array}$} & & $1.47^{\star \star \star}$ & $1.44^{\star \star \star}$ & $1.45^{\star \star \star}$ & & $1.40^{\star \star \star}$ & $1.38^{\star \star \star}$ & $1.38^{\star \star \star}$ \\
\hline & & $(6.41)$ & (6.05) & (6.09) & & (5.13) & $(4.83)$ & $(4.90)$ \\
\hline \multirow[t]{2}{*}{ Farmer } & & 1.07 & 1.10 & 1.05 & & $1.31^{\star \star \star}$ & $1.30^{\star \star \star}$ & $1.25^{\star \star}$ \\
\hline & & $(0.60)$ & $(0.89)$ & $(0.45)$ & & $(3.08)$ & (2.99) & $(2.50)$ \\
\hline \multirow{2}{*}{$\begin{array}{l}\text { Craftsman, } \\
\text { shopkeeper }\end{array}$} & & $0.81^{\star \star \star}$ & 0.88 & 0.91 & & 1.07 & 1.13 & $1.16^{*}$ \\
\hline & & (2.69) & (1.57) & (1.27) & & $(0.87)$ & (1.49) & $(1.85)$ \\
\hline \multirow[t]{2}{*}{ Executive } & & $0.51^{\star \star \star}$ & $0.66^{\star \star \star}$ & $0.74^{\star \star \star}$ & & $0.70^{\star \star \star}$ & 0.82 & 0.86 \\
\hline & & $(5.86)$ & (3.54) & (2.59) & & $(2.68)$ & $(1.48)$ & (1.11) \\
\hline \multirow[t]{2}{*}{ Intermediary prof } & & $0.64^{\star \star \star}$ & $0.78^{\star \star}$ & $0.79^{\star \star}$ & & $0.70^{\star \star \star}$ & $0.78^{\star \star}$ & $0.81^{*}$ \\
\hline & & $(4.49)$ & $(2.50)$ & (2.33) & & (3.11) & $(2.18)$ & $(1.84)$ \\
\hline \multirow{2}{*}{$\begin{array}{l}\text { Skilled } \\
\text { worker/employee }\end{array}$} & & 0.98 & 1.01 & 1.02 & & 1.04 & 1.06 & 1.06 \\
\hline & & $(0.30)$ & $(0.15)$ & $(0.42)$ & & $(0.64)$ & $(0.88)$ & $(0.95)$ \\
\hline \multirow{2}{*}{$\begin{array}{l}\text { Professional } \\
\text { education }\end{array}$} & & & $0.85^{\star \star \star}$ & 1.00 & & & 0.93 & 0.95 \\
\hline & & & (2.82) & $(0.02)$ & & & (1.23) & $(0.77)$ \\
\hline \multirow{2}{*}{$\begin{array}{l}\text { Secondary } \\
\text { education }\end{array}$} & & & $0.68^{\star \star \star}$ & 0.99 & & & $0.78^{\star \star \star}$ & 0.96 \\
\hline & & & $(5.48)$ & $(0.13)$ & & & $(2.97)$ & $(0.44)$ \\
\hline \multirow[t]{2}{*}{ Tertiary education } & & & $0.49^{\star \star \star}$ & 0.97 & & & $0.64^{\star \star \star}$ & 1.04 \\
\hline & & & $(10.44)$ & $(0.35)$ & & & $(6.11)$ & $(0.48)$ \\
\hline \multirow[t]{2}{*}{ In education } & & & & $0.22^{\star \star \star}$ & & & & $0.39^{\star \star \star *}$ \\
\hline & & & & $(18.76)$ & & & & $(9.66)$ \\
\hline \multirow{2}{*}{$\begin{array}{l}\text { Stable } \\
\text { employment }\end{array}$} & & & & $1.11^{*}$ & & & & $1.40^{\star \star \star}$ \\
\hline & & & & (1.77) & & & & $(4.61)$ \\
\hline $\mathrm{N}$ & 15,730 & 15,730 & 15,730 & 22,722 & 16,965 & 16,965 & 16,965 & 24,365 \\
\hline
\end{tabular}

* $\mathrm{p}<0.1$; ** $\mathrm{p}<0.05 ;$ *** $\mathrm{p}<0.01$

Source: Calculations based on Trajectories and Origins survey (TeO), INED-INSEE, 2008

Coverage: Immigrants aged 18-60 who arrived single in metropolitan France, Native French aged 18-60 and descendants of immigrants aged $18-50$.

Model 1: controlled for origin, cohort, age, child conception.

Model 2: additionally controlled for social background and religiosity.

Model 3: additionally controlled for educational level.

Model 4: additionally controlled for being in education and in stable employment.

Robust $z$ statistics in parentheses

TV: time-varying variable 
Pailhé: Partnership dynamics across generations of immigration in France

Appendix 2: Relative risk of cohabiting union, by sex

\begin{tabular}{|c|c|c|c|c|c|c|c|c|}
\hline & \multicolumn{4}{|l|}{ Women } & \multicolumn{4}{|c|}{ Men } \\
\hline & Model 1 & Model 2 & Model 3 & Model 4 & Model 1 & Model 2 & Model 3 & Model 4 \\
\hline G1 Maghreb & $\begin{array}{l}0.40^{\star \star \star} \\
(9.81)\end{array}$ & $\begin{array}{l}0.45^{\star \star \star} \\
(8.28)\end{array}$ & $\begin{array}{l}0.45^{\star \star \star} \\
(8.40)\end{array}$ & $\begin{array}{l}0.50^{\star \star \star} \\
(7.33)\end{array}$ & $\begin{array}{l}0.68^{\star \star \star} \\
(5.38)\end{array}$ & $\begin{array}{l}0.82^{\star \star \star} \\
(2.60)\end{array}$ & $\begin{array}{l}0.83^{\star \star} \\
(2.43)\end{array}$ & $\begin{array}{l}0.88^{\star} \\
(1.74)\end{array}$ \\
\hline G1 Africa & $\begin{array}{l}0.64^{\star \star \star} \\
(5.21)\end{array}$ & $\begin{array}{l}0.69^{\star \star \star} \\
(4.23)\end{array}$ & $\begin{array}{l}0.69^{\star \star \star} \\
(4.19)\end{array}$ & $\begin{array}{l}0.82^{\star \star} \\
(2.22)\end{array}$ & $\begin{array}{l}1.34^{\star \star \star} \\
(3.94)\end{array}$ & $\begin{array}{l}1.48^{\star \star \star} \\
(5.11)\end{array}$ & $\begin{array}{l}1.52^{\star \star \star} \\
(5.38)\end{array}$ & $\begin{array}{l}1.82^{\star \star \star} \\
(7.66)\end{array}$ \\
\hline \multirow[t]{2}{*}{$\begin{array}{l}\text { G1 Southeast } \\
\text { Asia }\end{array}$} & $0.70^{\star \star \star}$ & $0.71^{\star \star \star}$ & $0.71^{\star \star \star}$ & $0.73^{\star \star \star}$ & $0.59^{\star \star \star}$ & $0.61^{\star \star \star}$ & $0.63^{\star \star \star}$ & $0.65^{\star \star \star}$ \\
\hline & (3.65) & (3.56) & (3.53) & (3.23) & (5.99) & (5.54) & $(5.24)$ & $(4.77)$ \\
\hline G1 Turkey & $\begin{array}{l}0.33^{\star \star \star} \\
(5.71)\end{array}$ & $\begin{array}{l}0.35^{\star \star \star} \\
(5.37)\end{array}$ & $\begin{array}{l}0.35^{\star \star \star} \\
(5.39)\end{array}$ & $\begin{array}{l}0.37^{\star \star \star} \\
(5.03)\end{array}$ & $\begin{array}{l}0.57^{\star \star \star *} \\
(3.95)\end{array}$ & $\begin{array}{l}0.67^{\star \star \star} \\
(2.72)\end{array}$ & $\begin{array}{l}0.70^{\star \star} \\
(2.43)\end{array}$ & $\begin{array}{l}0.68^{\star \star \star} \\
(2.64)\end{array}$ \\
\hline \multirow[t]{2}{*}{$\begin{array}{l}\text { G1 Southern } \\
\text { Europe }\end{array}$} & 0.93 & 1.00 & 0.98 & 0.93 & 1.07 & $1.24^{\star \star \star}$ & $1.24^{\star \star \star}$ & $1.17^{\star \star}$ \\
\hline & (0.89) & $(0.04)$ & $(0.24)$ & $(0.91)$ & $(0.97)$ & (2.81) & $(2.80)$ & $(2.04)$ \\
\hline G2 Maghreb & $\begin{array}{c}0.39^{\star \star \star} \\
(15.44)\end{array}$ & $\begin{array}{c}0.43^{\star \star \star} \\
(13.34)\end{array}$ & $\begin{array}{c}0.42^{\star \star \star} \\
(13.45)\end{array}$ & $\begin{array}{c}0.44^{\star \star \star} \\
(13.06)\end{array}$ & $\begin{array}{c}0.46^{\star \star \star} \\
(11.55)\end{array}$ & $\begin{array}{l}0.53^{\star \star \star} \\
(9.30)\end{array}$ & $\begin{array}{l}0.54^{\star \star \star} \\
(9.07)\end{array}$ & $\begin{array}{l}0.55^{\star \star \star} \\
(8.70)\end{array}$ \\
\hline G2 Africa & $\begin{array}{l}0.40^{\star \star \star} \\
(8.66)\end{array}$ & $\begin{array}{l}0.45^{\star \star \star} \\
(7.65)\end{array}$ & $\begin{array}{l}0.45^{\star \star \star} \\
(7.67)\end{array}$ & $\begin{array}{l}0.48^{\star \star \star} \\
(6.85)\end{array}$ & $\begin{array}{l}0.48^{\star \star \star} \\
(6.05)\end{array}$ & $\begin{array}{l}0.55^{\star \star \star} \\
(4.86)\end{array}$ & $\begin{array}{l}0.57^{\star \star \star} \\
(4.70)\end{array}$ & $\begin{array}{l}0.60^{\star \star \star} \\
(4.24)\end{array}$ \\
\hline \multirow[t]{2}{*}{$\begin{array}{l}\text { G2 Southeast } \\
\text { Asia }\end{array}$} & $0.78^{\star \star}$ & $0.81^{\star \star}$ & $0.82^{\star}$ & 0.90 & $0.64^{\star \star \star}$ & $0.64^{\star \star \star}$ & $0.65^{\star \star \star}$ & $0.68^{\star \star \star}$ \\
\hline & $(2.45)$ & $(2.03)$ & (1.91) & (1.07) & (3.56) & (3.58) & (3.52) & $(3.16)$ \\
\hline G2 Turkey & $\begin{array}{l}0.21^{\star \star \star} \\
(6.88)\end{array}$ & $\begin{array}{l}0.23^{\star \star \star} \\
(6.37)\end{array}$ & $\begin{array}{l}0.23^{\star \star \star} \\
(6.45)\end{array}$ & $\begin{array}{l}0.22^{\star \star \star} \\
(6.59)\end{array}$ & $\begin{array}{l}0.35^{\star \star \star} \\
(5.19)\end{array}$ & $\begin{array}{l}0.42^{\star \star \star} \\
(4.26)\end{array}$ & $\begin{array}{l}0.42^{\star \star \star} \\
(4.29)\end{array}$ & $\begin{array}{l}0.42^{\star \star \star} \\
(4.32)\end{array}$ \\
\hline \multirow[t]{2}{*}{$\begin{array}{l}\text { G2 Southern } \\
\text { Europe }\end{array}$} & $0.83^{\star \star \star}$ & $0.83^{\star \star \star}$ & $0.83^{\star \star \star}$ & $0.81^{\star \star \star}$ & 0.97 & 1.01 & 1.02 & 0.99 \\
\hline & $(4.05)$ & (3.74) & (3.92) & $(4.31)$ & $(0.68)$ & $(0.24)$ & $(0.39)$ & $(0.18)$ \\
\hline Aged 20-24 & $\begin{array}{c}3.32^{\star \star \star} \\
(28.20)\end{array}$ & $\begin{array}{c}3.33^{\star \star \star} \\
(28.25)\end{array}$ & $\begin{array}{c}3.37^{\star \star \star} \\
(28.37)\end{array}$ & $\begin{array}{l}1.88^{\star \star \star} \\
(12.67)\end{array}$ & $\begin{array}{l}3.86^{\star \star \star} \\
(27.78)\end{array}$ & $\begin{array}{l}3.87^{\star \star \star *} \\
(27.83)\end{array}$ & $\begin{array}{l}3.86^{\star \star \star} \\
(27.76)\end{array}$ & $\begin{array}{l}2.50^{\star \star \star} \\
(16.78)\end{array}$ \\
\hline Aged 25-29 & $\begin{array}{l}3.33^{\star \star \star} \\
(21.29)\end{array}$ & $\begin{array}{c}3.33^{\star \star \star} \\
(21.30)\end{array}$ & $\begin{array}{l}3.38^{\star \star \star \star} \\
(21.45)\end{array}$ & $\begin{array}{l}1.43^{\star \star \star} \\
(5.37)\end{array}$ & $\begin{array}{c}5.10^{\star \star \star} \\
(29.10)\end{array}$ & $\begin{array}{l}5.12^{\star \star \star *} \\
(29.17)\end{array}$ & $\begin{array}{l}5.13^{\star \star \star} \\
(29.16)\end{array}$ & $\begin{array}{l}2.69 \star \star \star \\
(14.94)\end{array}$ \\
\hline Aged 30-34 & $\begin{array}{l}1.93^{\star \star \star} \\
(7.01)\end{array}$ & $\begin{array}{l}1.93^{\star \star \star} \\
(7.04)\end{array}$ & $\begin{array}{l}1.95^{\star \star \star} \\
(7.14)\end{array}$ & $\begin{array}{c}0.83^{*} \\
(1.88)\end{array}$ & $\begin{array}{l}3.62^{\star \star \star} \\
(15.87)\end{array}$ & $\begin{array}{l}3.69^{\star * *} \\
(16.14)\end{array}$ & $\begin{array}{l}3.73^{\star \star \star} \\
(16.24)\end{array}$ & $\begin{array}{l}1.93^{\star \star \star} \\
(7.43)\end{array}$ \\
\hline Aged 35-40 & $\begin{array}{c}0.71^{\star} \\
(1.75)\end{array}$ & $\begin{array}{c}0.71^{\star} \\
(1.72)\end{array}$ & $\begin{array}{r}0.72^{\star} \\
(1.66)\end{array}$ & $\begin{array}{l}0.31^{\star \star \star *} \\
(5.80)\end{array}$ & $\begin{array}{l}2.17^{\star \star \star} \\
(5.61)\end{array}$ & $\begin{array}{l}2.22^{\star \star \star} \\
(5.75)\end{array}$ & $\begin{array}{l}2.25^{\star \star \star} \\
(5.85)\end{array}$ & $\begin{array}{l}1.20 \\
(1.30)\end{array}$ \\
\hline Aged 45+ & $\begin{array}{c}0.75 \\
(1.01)\end{array}$ & $\begin{array}{c}0.75 \\
(1.01)\end{array}$ & $\begin{array}{c}0.76 \\
(0.99)\end{array}$ & $\begin{array}{l}0.34^{\star \star \star} \\
(3.77)\end{array}$ & $\begin{array}{l}2.02^{\star \star \star} \\
(3.35)\end{array}$ & $\begin{array}{l}2.06^{\star \star \star} \\
(3.44)\end{array}$ & $\begin{array}{l}2.11^{\star \star \star} \\
(3.54)\end{array}$ & $\begin{array}{l}1.13 \\
(0.59)\end{array}$ \\
\hline & $1.44^{\star \star \star}$ & $1.40^{\star \star \star}$ & $1.41^{\star \star \star}$ & $1.51^{\star \star \star}$ & $1.42^{\star \star \star}$ & $1.39^{\star \star \star}$ & $1.36^{\star \star \star}$ & $1.40^{\star \star \star}$ \\
\hline Cohort & $(6.07)$ & (5.66) & $(5.71)$ & $(6.81)$ & $(6.29)$ & (5.88) & (5.54) & $(6.03)$ \\
\hline $1971-80$ & $1.66^{\star \star \star}$ & $1.61^{\star \star \star}$ & $1.66^{\star \star \star}$ & $1.88^{\star \star \star}$ & $1.58^{\star \star \star}$ & $1.52^{\star \star \star}$ & $1.51^{\star \star \star}$ & $1.56^{\star \star \star}$ \\
\hline Cohort & (8.41) & (7.82) & $(8.22)$ & (10.08) & (7.98) & $(7.26)$ & (7.05) & (7.59) \\
\hline 1980-90 & $1.40^{\star \star \star}$ & $1.34^{\star \star \star}$ & $1.38^{\star \star \star}$ & $1.71^{\star \star \star}$ & $1.20^{\star \star}$ & $1.16^{\star \star}$ & $1.15^{\star}$ & $1.29^{\star \star \star}$ \\
\hline Cohort & $(4.60)$ & (3.97) & $(4.31)$ & (7.19) & $(2.48)$ & (1.98) & $(1.90)$ & $(3.41)$ \\
\hline $\begin{array}{l}\text { Child } \\
\text { conception }\end{array}$ & $\begin{array}{l}2.17^{\star \star \star} \\
(12.81)\end{array}$ & $\begin{array}{l}2.19^{\star \star \star} \\
(12.84)\end{array}$ & $\begin{array}{l}2.14^{\star \star \star} \\
(12.06)\end{array}$ & $\begin{array}{c}2.16^{\star \star \star} \\
(12.28)\end{array}$ & $\begin{array}{l}4.10^{\star \star \star} \\
(20.96)\end{array}$ & $\begin{array}{l}4.17^{\star \star \star} \\
(21.10)\end{array}$ & $\begin{array}{l}4.21^{\star \star \star} \\
(21.10)\end{array}$ & $\begin{array}{l}4.25^{\star \star \star} \\
(21.35)\end{array}$ \\
\hline $\begin{array}{l}\text { Religion not } \\
\text { important }\end{array}$ & & $\begin{array}{l}1.17^{\star \star \star} \\
(3.41)\end{array}$ & $\begin{array}{l}1.16^{\star \star \star} \\
(3.19)\end{array}$ & $\begin{array}{l}1.15^{\star \star \star} \\
(3.09)\end{array}$ & & $\begin{array}{l}1.08 \\
(1.62)\end{array}$ & $\begin{array}{l}1.07 \\
(1.54)\end{array}$ & $\begin{array}{l}1.06 \\
(1.25)\end{array}$ \\
\hline $\begin{array}{l}\text { Religion rather } \\
\text { important }\end{array}$ & & 0.94 & 0.94 & 0.94 & & $0.88^{\star \star}$ & $0.87^{\star \star}$ & $0.88^{\star \star}$ \\
\hline
\end{tabular}


Appendix 2: (Continued)

\begin{tabular}{|c|c|c|c|c|c|c|c|c|}
\hline & \multicolumn{4}{|l|}{ Women } & \multicolumn{4}{|c|}{ Men } \\
\hline & Model 1 & Model 2 & Model 3 & Model 4 & Model 1 & Model 2 & Model 3 & Model 4 \\
\hline & & $(1.17)$ & $(1.12)$ & $(1.11)$ & & $(2.34)$ & $(2.55)$ & $(2.42)$ \\
\hline \multirow{2}{*}{$\begin{array}{l}\text { Religion very } \\
\text { important }\end{array}$} & & $0.84^{\star \star \star}$ & $0.84^{\star \star \star}$ & $0.84^{\star \star \star}$ & & $0.74^{\star \star \star}$ & $0.75^{\star \star \star}$ & $0.74^{\star \star \star}$ \\
\hline & & $(3.32)$ & $(3.36)$ & (3.17) & & $(5.36)$ & (5.31) & $(5.37)$ \\
\hline \multirow[t]{2}{*}{ Farmer } & & 1.11 & 1.12 & 1.11 & & $1.18^{*}$ & $1.19^{\star \star}$ & 1.14 \\
\hline & & $(1.00)$ & $(1.13)$ & $(1.06)$ & & $(1.88)$ & $(1.99)$ & $(1.50)$ \\
\hline \multirow{2}{*}{$\begin{array}{l}\text { Craftsman, } \\
\text { shopkeeper }\end{array}$} & & $1.30^{\star \star \star}$ & $1.32^{\star \star \star}$ & $1.35^{\star \star \star}$ & & $1.50^{\star \star \star}$ & $1.50^{\star \star \star}$ & $1.55^{\star \star \star}$ \\
\hline & & $(4.28)$ & $(4.51)$ & $(4.91)$ & & $(6.41)$ & $(6.42)$ & $(6.91)$ \\
\hline \multirow[t]{2}{*}{ Executive } & & 1.07 & $1.13^{\star}$ & $1.24^{\star \star \star}$ & & $1.47^{\star \star \star}$ & $1.48^{\star \star \star}$ & $1.58^{\star \star \star}$ \\
\hline & & $(1.00)$ & $(1.66)$ & $(2.93)$ & & $(5.12)$ & $(4.99)$ & $(5.85)$ \\
\hline \multirow[t]{2}{*}{ Intermediary prof } & & $1.12^{\star}$ & $1.16^{\star \star}$ & $1.18^{\star *}$ & & $1.34^{\star \star \star}$ & $1.34^{\star \star \star}$ & $1.39^{\star \star \star}$ \\
\hline & & $(1.76)$ & $(2.27)$ & $(2.53)$ & & $(4.45)$ & $(4.38)$ & $(4.91)$ \\
\hline \multirow{2}{*}{$\begin{array}{l}\text { Skilled } \\
\text { worker/employee }\end{array}$} & & $1.20^{\star \star \star}$ & $1.21^{\star \star \star}$ & $1.21^{\star \star \star}$ & & $1.22^{\star \star \star}$ & $1.21^{\star \star \star}$ & $1.22^{\star \star \star}$ \\
\hline & & $(3.61)$ & $(3.67)$ & (3.70) & & $(3.87)$ & $(3.73)$ & $(3.86)$ \\
\hline \multirow{2}{*}{$\begin{array}{l}\text { Professional } \\
\text { education }\end{array}$} & & & $1.13^{\star \star}$ & $1.17^{\star \star \star}$ & & & $1.23^{\star \star \star}$ & $1.22^{\star \star \star}$ \\
\hline & & & $(2.27)$ & $(2.78)$ & & & $(4.17)$ & $(3.90)$ \\
\hline \multirow{2}{*}{$\begin{array}{l}\text { Secondary } \\
\text { education }\end{array}$} & & & 0.97 & $1.18^{\star \star \star}$ & & & 1.03 & $1.19^{\star \star \star}$ \\
\hline & & & $(0.51)$ & $(2.73)$ & & & $(0.56)$ & $(2.97)$ \\
\hline \multirow{2}{*}{$\begin{array}{l}\text { Tertiary } \\
\text { education }\end{array}$} & & & 0.93 & $1.40^{\star \star \star}$ & & & $1.10^{\star}$ & $1.55^{\star \star \star}$ \\
\hline & & & $(1.42)$ & (5.79) & & & $(1.90)$ & (7.79) \\
\hline \multirow[t]{2}{*}{ In education } & & & & $0.48^{\star \star \star}$ & & & & $0.54^{\star \star \star}$ \\
\hline & & & & $(11.82)$ & & & & $(8.71)$ \\
\hline \multirow{3}{*}{$\begin{array}{l}\text { Stable } \\
\text { employment }\end{array}$} & & & & $1.71^{\star \star \star}$ & & & & $1.54^{\star \star \star}$ \\
\hline & & & & (9.66) & & & & (7.06) \\
\hline & 15,737 & 15,737 & 15,737 & 22,733 & 16,974 & 16,974 & 16,974 & 24,380 \\
\hline
\end{tabular}

${ }^{*} p<0.1 ;{ }^{* \star} p<0.05 ; * \star *<0.01$

Source: Calculations based on Trajectories and Origins survey (TeO), INED-INSEE, 2008

Coverage: Immigrants aged 18-60 who arrived single in metropolitan France, Native French aged $18-60$ and descendants of immigrants aged $18-50$.

Model 1: controlled for origin, cohort, age, child conception.

Model 2: additionally controlled for social background and religiosity.

Model 3: additionally controlled for educational level.

Model 4: additionally controlled for being in education and in stable employment.

Robust $z$ statistics in parentheses

TV: time-varying variable 
Pailhé: Partnership dynamics across generations of immigration in France

\section{Appendix 3: Relative risk of transition from cohabitation to marriage, by country of origin}

\begin{tabular}{|c|c|c|c|c|c|c|c|c|}
\hline & \multicolumn{4}{|l|}{ Women } & \multicolumn{4}{|c|}{ Men } \\
\hline & Model 1 & Model 2 & Model 3 & Model 4 & Model 1 & Model 2 & Model 3 & Model 4 \\
\hline \multirow[t]{2}{*}{ G1 Maghreb } & $1.70^{\star \star \star}$ & $1.68^{\star \star \star}$ & $1.72^{\star \star \star}$ & $1.74^{\star \star \star}$ & $1.35^{\star \star}$ & 1.24 & 1.25 & 1.29 \\
\hline & $(3.35)$ & (3.09) & (3.13) & (3.13) & $(2.15)$ & $(1.38)$ & $(1.43)$ & $(1.62)$ \\
\hline \multirow[t]{2}{*}{ G1 Africa } & 1.07 & 1.23 & 1.27 & 1.27 & 1.25 & 1.06 & 1.01 & 1.02 \\
\hline & $(0.43)$ & $(1.21)$ & $(1.37)$ & $(1.37)$ & $(1.51)$ & $(0.35)$ & $(0.05)$ & $(0.14)$ \\
\hline \multirow[t]{2}{*}{ G1 Southeast Asia } & 1.30 & 1.27 & 1.29 & 1.28 & 1.00 & 0.91 & 0.94 & 0.97 \\
\hline & $(1.54)$ & $(1.36)$ & $(1.46)$ & $(1.41)$ & $(0.00)$ & $(0.45)$ & $(0.32)$ & $(0.16)$ \\
\hline \multirow[t]{2}{*}{ G1 Turkey } & $3.34^{\star \star \star}$ & $3.09^{\star \star \star}$ & $3.10^{\star \star \star}$ & $3.06^{\star \star \star}$ & $3.05^{\star \star \star}$ & $2.86^{\star \star \star}$ & $2.92^{\star \star \star}$ & $3.00^{\star \star \star}$ \\
\hline & $(3.97)$ & $(3.48)$ & $(3.41)$ & $(3.36)$ & $(5.09)$ & $(4.80)$ & $(4.69)$ & $(4.80)$ \\
\hline \multirow[t]{2}{*}{ G1 Southern Europe } & $1.37^{\star \star}$ & $1.33^{\star \star}$ & $1.37^{\star \star}$ & $1.39 * \star$ & 1.10 & 1.06 & 1.13 & 1.15 \\
\hline & $(2.52)$ & $(2.09)$ & $(2.20)$ & $(2.28)$ & $(0.74)$ & $(0.39)$ & $(0.86)$ & $(0.93)$ \\
\hline \multirow[t]{2}{*}{ G2 Maghreb } & 0.98 & 0.95 & 0.97 & 0.97 & 0.90 & 0.92 & 0.96 & 0.98 \\
\hline & $(0.18)$ & $(0.42)$ & $(0.29)$ & $(0.25)$ & $(0.82)$ & $(0.64)$ & $(0.28)$ & $(0.19)$ \\
\hline \multirow[t]{2}{*}{ G2 Africa } & 0.70 & 0.73 & 0.73 & 0.73 & 1.44 & 1.36 & 1.42 & 1.39 \\
\hline & $(1.53)$ & $(1.33)$ & $(1.36)$ & $(1.36)$ & $(0.83)$ & $(0.75)$ & $(0.80)$ & $(0.77)$ \\
\hline \multirow[t]{2}{*}{ G2 Southeast Asia } & 1.27 & 1.35 & 1.36 & 1.35 & $1.49^{\star \star}$ & $1.54^{\star \star}$ & $1.47^{\star \star}$ & $1.47^{\star \star}$ \\
\hline & $(0.96)$ & $(1.24)$ & $(1.28)$ & $(1.24)$ & $(2.30)$ & $(2.41)$ & $(2.03)$ & $(2.05)$ \\
\hline \multirow[t]{2}{*}{ G2 Turkey } & $0.05^{\star \star \star}$ & $0.05^{\star \star \star}$ & $0.05^{\star \star \star}$ & $0.05^{\star \star \star}$ & 0.65 & 0.54 & 0.51 & 0.52 \\
\hline & $(2.86)$ & $(2.78)$ & $(2.77)$ & $(2.77)$ & $(0.91)$ & $(1.26)$ & (1.32) & $(1.30)$ \\
\hline \multirow[t]{2}{*}{ G2 Southern Europe } & 1.03 & 1.00 & 1.00 & 1.00 & 0.78 & 0.80 & 0.82 & 0.83 \\
\hline & $(0.24)$ & $(0.03)$ & $(0.01)$ & $(0.01)$ & (1.49) & $(1.42)$ & $(1.31)$ & $(1.31)$ \\
\hline \multirow{2}{*}{$\begin{array}{l}1-3 \text { years } \\
\text { cohabitation }\end{array}$} & 0.91 & 0.92 & 0.92 & 0.93 & 0.93 & 0.95 & 0.95 & 0.94 \\
\hline & $(0.82)$ & $(0.73)$ & $(0.74)$ & $(0.61)$ & $(0.59)$ & $(0.44)$ & $(0.42)$ & $(0.48)$ \\
\hline \multirow{2}{*}{$\begin{array}{l}3-6 \text { years } \\
\text { cohabitation }\end{array}$} & $0.62^{\star \star \star}$ & $0.63^{\star \star \star}$ & $0.63^{\star \star \star}$ & $0.67^{\star \star \star}$ & $0.55^{\star \star \star}$ & $0.57^{\star \star \star}$ & $0.58^{\star \star \star}$ & $0.59^{\star \star \star}$ \\
\hline & (3.73) & $(3.56)$ & $(3.56)$ & $(2.74)$ & $(4.30)$ & $(4.13)$ & $(4.08)$ & $(3.47)$ \\
\hline \multirow{2}{*}{$\begin{array}{l}6-10 \text { years } \\
\text { cohabitation }\end{array}$} & $0.29^{* \star \star}$ & $0.30^{\star \star \star}$ & $0.29^{\star \star \star}$ & $0.33^{\star \star \star}$ & $0.29^{\star \star \star}$ & $0.30^{\star \star \star}$ & $0.30^{\star \star \star \star}$ & $0.32^{\star \star \star}$ \\
\hline & $(7.56)$ & (7.34) & $(7.36)$ & (5.31) & $(7.45)$ & (7.31) & $(7.22)$ & (5.99) \\
\hline \multirow{2}{*}{$\begin{array}{l}10+\text { years } \\
\text { cohabitation }\end{array}$} & $0.12^{\star \star \star}$ & $0.12^{\star \star \star}$ & $0.12^{\star \star \star}$ & $0.14^{\star \star \star}$ & $0.10^{\star \star \star}$ & $0.10^{\star \star \star}$ & $0.10^{\star \star \star}$ & $0.11^{\star \star \star}$ \\
\hline & (8.39) & $(8.26)$ & $(8.26)$ & $(6.85)$ & $(9.47)$ & $(9.29)$ & $(9.33)$ & (8.09) \\
\hline \multirow[t]{2}{*}{ 1961-70 Cohort } & $0.69^{\star \star \star}$ & $0.67^{\star \star \star}$ & $0.67^{\star \star \star}$ & $0.66^{\star \star \star}$ & $0.67^{\star \star \star}$ & $0.68^{\star \star \star}$ & $0.66^{\star \star \star}$ & $0.67^{\star \star \star}$ \\
\hline & $(2.59)$ & $(2.82)$ & $(2.86)$ & $(2.91)$ & $(2.76)$ & $(2.74)$ & $(2.94)$ & $(2.90)$ \\
\hline \multirow[t]{2}{*}{ 1971-80 Cohort } & $0.53^{\star \star \star}$ & $0.52^{\star \star \star}$ & $0.51^{\star \star \star}$ & $0.50^{\star \star \star}$ & $0.47^{\star \star \star}$ & $0.47^{\star \star \star}$ & $0.44^{\star \star \star}$ & $0.44^{\star \star \star}$ \\
\hline & $(4.27)$ & $(4.46)$ & $(4.60)$ & $(4.63)$ & $(4.82)$ & $(5.13)$ & $(5.52)$ & $(5.42)$ \\
\hline \multirow[t]{2}{*}{ 1980-90 Cohort } & $0.19^{\star \star \star}$ & $0.19^{\star \star \star}$ & $0.18^{\star \star \star}$ & $0.18^{\star \star \star}$ & $0.23^{\star \star \star}$ & $0.24^{\star \star \star}$ & $0.22^{\star \star \star}$ & $0.22^{\star \star \star}$ \\
\hline & $(6.55)$ & $(6.58)$ & $(6.72)$ & $(6.71)$ & $(5.27)$ & $(5.04)$ & $(5.35)$ & $(5.32)$ \\
\hline \multirow[t]{2}{*}{ Aged 15-19 } & 1.01 & 0.97 & 0.99 & 0.99 & $0.58^{\star \star \star}$ & $0.54^{\star \star \star}$ & $0.58^{\star \star \star}$ & $0.58^{\star \star \star}$ \\
\hline & $(0.06)$ & $(0.32)$ & $(0.09)$ & $(0.10)$ & $(3.10)$ & $(3.43)$ & $(2.97)$ & $(2.98)$ \\
\hline \multirow[t]{2}{*}{ Aged 25-29 } & $0.75^{\star \star}$ & $0.74^{\star \star}$ & $0.73^{\star \star}$ & $0.73^{\star \star}$ & 0.88 & 0.87 & 0.85 & 0.85 \\
\hline & (2.11) & $(2.23)$ & $(2.26)$ & $(2.26)$ & $(0.88)$ & $(1.05)$ & $(1.20)$ & $(1.20)$ \\
\hline \multirow[t]{2}{*}{ Aged $30-45$} & $0.37^{\star \star \star}$ & $0.34^{\star \star \star}$ & $0.34^{\star \star \star}$ & $0.34^{\star \star \star}$ & $0.46^{\star \star \star}$ & $0.44^{\star \star \star}$ & $0.44^{\star \star \star}$ & $0.45^{\star \star \star}$ \\
\hline & (3.67) & (3.75) & (3.79) & (3.79) & $(3.72)$ & $(3.80)$ & (3.82) & $(3.74)$ \\
\hline Child conception & 0.79 & 0.76 & 0.78 & 0.79 & $1.96^{\star \star \star}$ & $1.95^{\star \star \star}$ & $1.93^{\star \star}$ & $1.94^{\star \star}$ \\
\hline & (1.03) & $(1.20)$ & (1.03) & $(0.97)$ & $(2.65)$ & $(2.60)$ & (2.52) & $(2.53)$ \\
\hline Religion no & & 0.99 & 1.00 & 1.00 & & 1.14 & 1.15 & 1.15 \\
\hline & & $(0.11)$ & $(0.03)$ & $(0.01)$ & & $(1.02)$ & (1.11) & $(1.12)$ \\
\hline
\end{tabular}




\section{Appendix 3: (Continued)}

\begin{tabular}{|c|c|c|c|c|c|c|c|c|}
\hline & \multicolumn{4}{|l|}{ Women } & \multicolumn{4}{|l|}{ Men } \\
\hline & Model 1 & Model 2 & Model 3 & Model 4 & Model 1 & Model 2 & Model 3 & Model 4 \\
\hline \multirow{2}{*}{$\begin{array}{l}\text { Religion rather } \\
\text { important }\end{array}$} & & 1.16 & 1.17 & 1.16 & & $1.36^{\star \star}$ & $1.29^{*}$ & $1.28^{\star}$ \\
\hline & & $(1.08)$ & $(1.17)$ & $(1.12)$ & & $(2.03)$ & $(1.70)$ & $(1.67)$ \\
\hline \multirow[t]{2}{*}{ Religion very important } & & $0.75^{\star}$ & $0.75^{\star}$ & $0.74^{\star}$ & & $1.40^{*}$ & 1.37 & 1.36 \\
\hline & & $(1.71)$ & $(1.72)$ & $(1.74)$ & & $(1.72)$ & $(1.60)$ & $(1.58)$ \\
\hline \multirow[t]{2}{*}{ Farmer } & & 1.07 & 1.06 & 1.07 & & $1.46^{*}$ & 1.42 & 1.43 \\
\hline & & $(0.35)$ & $(0.28)$ & $(0.31)$ & & $(1.66)$ & $(1.56)$ & $(1.58)$ \\
\hline \multirow[t]{2}{*}{ Craftsman, shopkeeper } & & 1.05 & 1.03 & 1.02 & & $1.48^{\star \star}$ & 1.34 & $1.36^{*}$ \\
\hline & & $(0.32)$ & $(0.16)$ & $(0.14)$ & & $(2.16)$ & $(1.61)$ & $(1.69)$ \\
\hline \multirow[t]{2}{*}{ Executive } & & $0.62^{\star *}$ & $0.59^{\star \star}$ & $0.59^{\star \star}$ & & 0.87 & 0.76 & 0.77 \\
\hline & & $(2.26)$ & $(2.42)$ & $(2.47)$ & & $(0.62)$ & $(1.24)$ & $(1.17)$ \\
\hline \multirow[t]{2}{*}{ Intermediary prof } & & 0.86 & 0.82 & 0.82 & & $1.35^{*}$ & 1.19 & 1.21 \\
\hline & & $(0.90)$ & $(1.12)$ & $(1.13)$ & & $(1.68)$ & $(0.98)$ & $(1.06)$ \\
\hline \multirow[t]{2}{*}{ Skilled worker/employee } & & 1.00 & 0.99 & 0.99 & & 1.14 & 1.11 & 1.11 \\
\hline & & $(0.02)$ & $(0.04)$ & $(0.07)$ & & $(0.82)$ & $(0.66)$ & $(0.67)$ \\
\hline \multirow[t]{2}{*}{ Professional education } & & & 1.06 & 1.04 & & & 1.05 & 1.03 \\
\hline & & & $(0.38)$ & $(0.22)$ & & & $(0.35)$ & $(0.18)$ \\
\hline \multirow[t]{2}{*}{ Secondary education } & & & 1.14 & 1.08 & & & 1.31 & 1.28 \\
\hline & & & $(0.74)$ & $(0.42)$ & & & $(1.48)$ & $(1.26)$ \\
\hline \multirow[t]{2}{*}{ Tertiary education } & & & 1.16 & 1.09 & & & $1.43^{\star *}$ & $1.38^{*}$ \\
\hline & & & $(0.88)$ & $(0.44)$ & & & $(2.33)$ & $(1.88)$ \\
\hline \multirow[t]{2}{*}{ In education } & & & & 1.18 & & & & 1.31 \\
\hline & & & & $(0.95)$ & & & & $(1.60)$ \\
\hline \multirow[t]{2}{*}{ Stable employment } & & & & 1.02 & & & & 1.25 \\
\hline & & & & $(0.10)$ & & & & $(1.50)$ \\
\hline $\mathrm{N}$ & 9,677 & 9,677 & 9,677 & 10,967 & 9,450 & 9,450 & 9,450 & 10,665 \\
\hline
\end{tabular}

${ }^{\star} p<0.1 ; * \star p<0.05 ; * \star *<<0.01$

Source: Calculations based on Trajectories and Origins survey (TeO), INED-INSEE, 2008

Coverage: Immigrants aged 18-60 who arrived single in metropolitan France, Native French aged $18-60$ and descendants of immigrants aged $18-50$.

Model 1: controlled for origin, cohort, duration of cohabitation, age at cohabitation, child conception.

Model 2: additionally controlled for social background and religiosity.

Model 3: additionally controlled for educational level.

Model 4: additionally controlled for being in education and in stable employment.

Robust $z$ statistics in parentheses

TV: time-varying variable 
Pailhé: Partnership dynamics across generations of immigration in France 